\title{
Review
}

\section{Mechanisms of flavoprotein-catalyzed reactions}

\author{
Sandro GHISLA ${ }^{1}$ and Vincent MASSEY ${ }^{2}$ \\ 1 Fakultät für Biologie der Universität Konstanz \\ 2 Department of Biological Chemistry, University of Michigan, Ann Arbor
}

(Received September 30/December 14, 1988) - EJB 881152

Flavoproteins are a class of enzymes catalyzing a very broad spectrum of redox processes by different chemical mechanisms. This review describes the best studied of these mechanisms and discusses factors possibly governing reactivity and specificity.

A large number of flavin-containing enzymes, several hundreds, has been uncovered to date. An unusual feature of flavoproteins is the variety of the catalytic reactions performed, which range from typical redox catalysis such as the dehydrogenation of an amino acid, or the activation of dioxygen, to photochemistry; from 'DNA damage repair' to light emission. These few examples illustrate the fact that the same coenzyme is able to catalyze, or take part in catalytic events which must vary widely from a mechanistic point of view. The chemistry underlying the conversion itself will be quite different from case to case. This versatility sets flavoproteins apart from most other cofactor-dependent enzymes, which, in general, each catalyze a single type of chemical reaction. The activation or 'steering' of a particular activity of the flavin results from the interaction with the protein at the active center. On the other hand, for the vast majority of these enzymes a common feature exists, that at some stage during the catalytic event a transfer of electrons takes place between the substrate and the flavin itself.

The purpose of the present review is not to enumerate the different functions of flavoproteins, this having been done elsewhere [1 -4], but to focus on the mechanisms of catalysis, and on the possible ways of interaction of the flavin nucleus with the protein, i.e. on how this brings about chemistry appropriate to the particular enzyme reaction. In order to

Correspondence to S. Ghisla, Fakultät für Biologie der Universität Konstanz, D-7750 Konstanz, Federal Republic of Germany

Abbreviations. $\mathrm{Fl}$, flavin; $\mathrm{Fl}_{\mathrm{ox}}, \mathrm{FlH}, \mathrm{Fl}_{\text {red }}$, flavin in its oxidized, half-reduced (radical) and fully reduced (dihydro) forms; GSH, glutathione; GSSG, oxidized glutathione; $\mathrm{Nbs}_{2}$, bis(4-nitrophenyl)disulfide 3,3'-dicarboxylic acid, formerly named 5,5'-dithiobis(2-nitrobenzoic acid) and abbreviated to DTNB.

Enzymes. Glutathione reductase (EC 1.6.4.2); lipoyl dehydrogenase, dihydrolipoamide dehydrogenase (EC 1.8.1.4); mercuric reductase (EC 1.16.1.1); thioredoxin reductase (EC 1.6.4.5); $p$-hydroxybenzoate hydroxylase (EC 1.14.13.2); melilotate hydroxylase (EC 1.14.13.4); anthranilate hydroxylase (EC 1.14.12.2); 2-methyl-3-hydroxypyridine-5-carboxylic acid oxygenase (EC 1.14.12.4); cyclohexanone monooxygenase (EC 1.14.13.22); glucose oxidase (EC 1.1.3.4); acyl-CoA dehydrogenase (EC 1.3.99.3); D-amino acid oxidase (EC 1.4.3.3); L-lactate dehydrogenase, flavocytochrome $b_{2}$ (EC 1.1.2.3); D-lactate dehydrogenase (EC 1.1.2.4); trypanothione reductase (EC 1.6.4.-). understand how this is done we think it useful to reiterate briefly the chemical properties of the flavin itself.

\section{CHEMICAL PROPERTIES OF THE FLAVIN}

The following scheme will remind the reader of the structure of the redox-active part of the flavin molecule, the 7,8dimethylisoalloxazine, in its oxidized and fully reduced states, and the numbering of the most important functional groups.

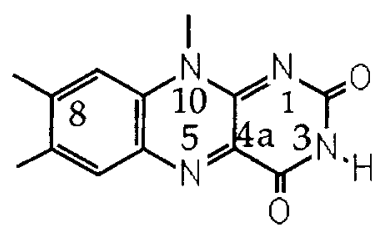

Oxidized flavin $\left(\mathrm{Fl}_{\mathrm{ox}}\right)$<smiles>Cc1cc2c(cc1C)N(C)c1[nH]c(=O)[nH]c(=O)c1N2</smiles>

Reduced flavin $\left(\mathrm{Fl}_{\text {red }} \mathrm{H}_{2}\right)$
The modes of modulation of flavin reactivity can be subdivided roughly into effects on the thermodynamics and those on the kinetics of a possible reaction. With respect to the first it should be pointed out that the redox chemistry of the flavin is restricted to the isoalloxazine nucleus, side-chain functions such as the adenine moiety not being involved in catalysis, but serving in anchoring the coenzyme at the active site. Reduction of the flavin occurs reversibly by two one-electron steps, or one two-electron step, involving changes which affect particularly the chemistry of the 'enediamine' subfunction and thus of positions $\mathrm{N}(1), \mathrm{C}(4 \mathrm{a})$ and $\mathrm{N}(5)$. The potential of this conversion $\left(E_{\mathrm{m}}, \mathrm{pH} 7\right)$ is around $-200 \mathrm{mV}$ and can be lowered or increased in an approximately $600-\mathrm{mV}$ range through interaction with the protein (from $-495 \mathrm{mV}$ for the $\mathrm{FlH} / \mathrm{Fl}_{\text {red }} \mathrm{H}^{-}$couple in Azotobacter vinelandii flavodoxin [5] to $+80 \mathrm{mV}$ for the $\mathrm{Fl}_{\mathrm{ox}} / \mathrm{Fl}^{-}$couple in thiamin dehydrogenase [6]). The pyrimidine nucleus of the three-membered ring system is electron-deficient and can be viewed as an 'electron sink'. In thermodynamic terms, any interaction which tends to lower its electron or negative charge density will increase the redox potential. The reduced flavin consists roughly of an electron-rich phenylenediamine moiety fused with a (4,5-diamino)-uracil. The latter is the moiety in which the negative charge (i.e. two electrons taken up by the oxidized flavin) is localized and, most importantly, stabilized. The de- 
gree to which this negative charge is stabilized or destabilized is an important factor governing the redox potential. Thus while a positive charge in the protein around the pyrimidine ring will contribute to increase the redox potential, the presence of negative charge or of a hydrophobic environment will lower it. These concepts have been put forward earlier [3, 71 and have, in their essence, been verified by recent X-ray crystallographic studies [8-11], as will be detailed below. The thermodynamic stabilization or destabilization of intermediate radical forms can be viewed along the same lines. An additional important factor affecting the redox potential is the modification of the flavin nucleus through introduction of functional groups. Thus introduction of an imidazolyl residue at position $8 \alpha$, such as in $8 \alpha$-histidyl-flavins, and the corresponding ionisation states, modulate the redox potential [12]. Similar effects are observed when the substitution is introduced directly into the aromatic system such as in 6-cysteinyl, 6-hydroxy or 8-hydroxy flavins [13-16]; in the latter two cases the redox potential is additionally affected by the ionization of the substituent.

With respect to the second, broad generalization, it is again important to point out that reactions of the flavin nucleus with a given substrate will occur preferentially at specific loci, which vary depending on the type of reaction. For example, activation of dioxygen to form hydroperoxides occurs through formation of a covalent adduct at position 4a of the flavin [17], oxidation of lactate by lactate oxidase via position $N(5)$ [18]. Thus steric restriction of access to the flavin itself, or to a specific position, can lower the rate of a reaction to essentially zero, while other reactions might remain unaffected. Conversely, facilitation of access or of encounter with specific reactants can make other reactions predominant or exclusive.

\section{MECHANISMS OF FLAVIN-CATALYZED DEIIYDROGENATION REACTIONS}

Most biological oxidation reactions involve the rupture of (at least) one organic-substrate $-\mathrm{H}$ bond, with concomitant transfer of two electrons to a suitable acceptor molecule. In the case of oxidation reactions catalyzed by simple pyridinenucleotide-linked enzymes, the acceptor is $\mathrm{NAD}^{+}$or $\mathrm{NADP}^{+}$ and the resultant $\mathrm{NAD}(\mathrm{P}) \mathrm{H}$ needs to be reoxidized by coupling with a second pyridine-nucleotide-linked enzyme. In the case of flavoproteins, the flavin being tightly bound to the protein, a second substrate serves to reoxidize the reduced flavin to complete the catalytic cycle. Thus catalysis by flavoprotein enzymes always involves a reductive half-reaction, where the enzyme-bound flavin is reduced, and an oxidative half-reaction, where the reduced flavin is reoxidized. In most cases it is possible to study these two half-reactions separately, a feature which has permitted the detailed analysis of catalytic events not possible with most other enzymes.

As detailed previously [3], we can conveniently distinguish four different types of substrates undergoing dehydrogenation reactions with flavoproteins; in each of these classes a different mechanism appears to exist.

\section{Pyridine nucleotides}

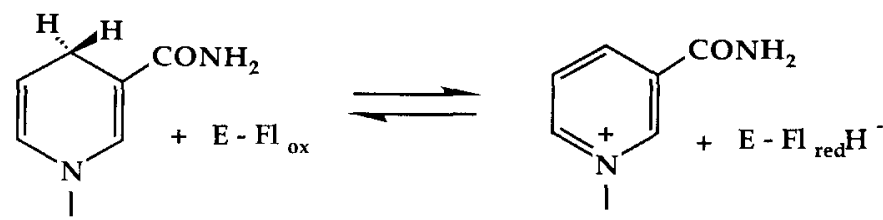

In these enzymes a direct transfer of a hydride equivalent appears to take place between the $\mathrm{C}(4)$ of the pyridine nucleotide and the $\mathrm{N}(5)$ position of the flavin, in accord with chemical model studies [19]. This concept is nicely supported by the crystallographic data on glutathione reductase, which shows the nicotinamide ring stacked over the flavin pyrazine ring with the $S$-hydrogen at its $C(4)$ position close to the flavin $\mathrm{N}(5)$ position [20]. Such a juxtaposition is essential for hydride transfer, in distinction to a radical mechanism, where orbital overlap between pyridine nucleotide and flavin would not have to be so restrictive.

\section{Substrates activated for carbanion transfer}

Many flavoprotein enzymes involve oxidation of substrates with electron-withdrawing activating groups next to the position of dehydrogenation. Such reactions appear to be initiated by abstraction of the relatively acidic $\alpha$-hydrogen atom as a proton and therefore involve formally a carbanion of the substrate, either as an intermediate or, at least, as a transition state $[21,22]$. These mechanisms have been described in detail in previous reviews $[1,3]$ and the evidence in their favor appears to be compelling. Therefore, here we will reiterate only the main points plus some relevant new information.

The best-characterized flavoprotein reaction appearing to proceed via a carbanion mechanism is the dehydrogenation of $\alpha$-hydroxy acids as exemplified by the enzymes L-lactate oxidase and flavocytochrome $b_{2}$ (yeast L-lactate dehydrogenase). In spite of basic agreement about the overall mechanism, some uncertainties remain which revolve around the mode of transfer of the redox equivalents from the carbanionic species to the flavin and the formation of the primary products. Before discussing this, the topology of the active center of flavocytochrome $b_{2}$, which has recently been solved by X-ray crystallography $[23,24]$ will be discussed in connection with structural evidence derived from work with L-lactate oxidase. As shown in Fig. 1, substrate (or product in the specific case) binds to the $S i$-side of the flavin. Therefore this side specificity seems to be a common theme in $\alpha$ hydroxyacid dehydrogenation, since it is found also with the recently reported crystal structure of spinach glycollate oxidase $[25]$ and with D-lactate dehydrogenase and L-lactate oxidase [26] (cf. Table 1).

The carboxylate function of substrate is bound to Arg-376 and placed near the benzene ring, while the $\alpha$-position is located near $\mathrm{N}(5)(374 \mathrm{pm})$, and the further $\alpha$-substituent $\left(-\mathrm{CH}_{3}\right.$ in the specific case) in a position where it can interact with the flavin $\mathrm{C}(4 \mathrm{a})$ as required for inactivation with suicide substrates [27-29]. This is in nice agreement with the mode of binding and the stereospecificity deduced from studies with L-lactate oxidase [26]. Of equal importance, the positive charge proposed to facilitate flavin reduction thermodynamically and to stabilize the binding of many anionic flavins $[3,7]$ is found as lysine 349 , which interacts with $\mathrm{N}(1)$ $\mathrm{C}(2)=\mathrm{O}$ in flavocytochrome $b_{2}$ (Fig. 1).

Of particular interest is His-373, which is in close contact (261 pm) with the carbonyl of pyruvate. Assuming homology between the two enzymes this would explain perfectly the tight and $\mathrm{pH}$-dependent binding of oxalate to lactate oxidase [30]. His-373 is thus in an appropriate position for $\alpha$-proton abstraction, this being possibly facilitated also by the interaction of the $\alpha$-hydroxy group with Tyr-254 [24].

For the transfer of redox equivalents from the assumed carbanion the following alternatives (Scheme 1) are possible: 


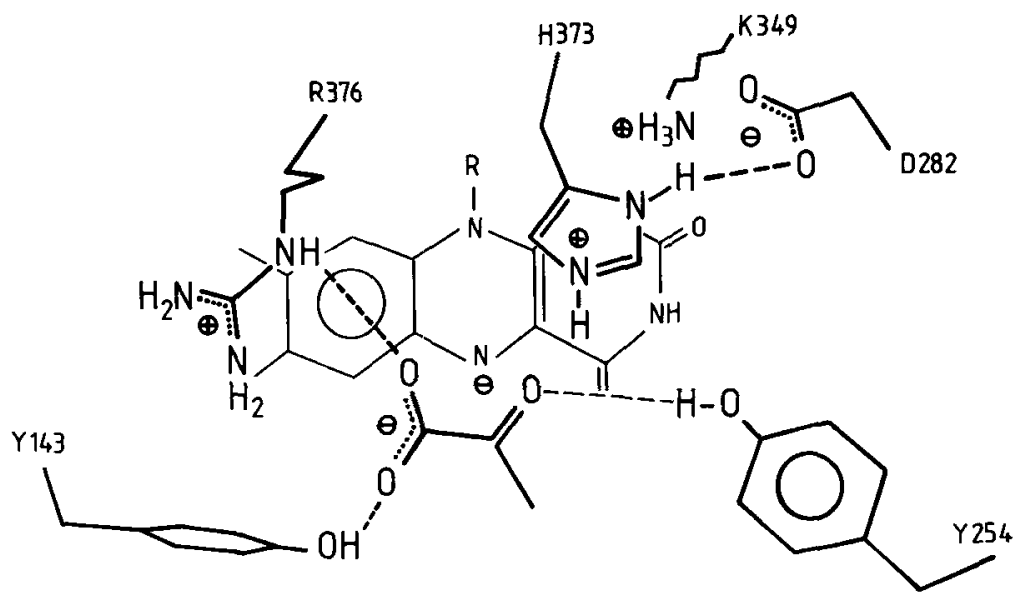

Fig. 1. Orientation of (dianionic) reduced flavin, pyruvate (product) and of relevant amino acid residues at the active center of yeast $L$-lactate dehydrogenase (flavocytochrome $\mathrm{b}_{2}$ ) as proposed by Lederer and Mathews [24]. Arg-376, His-373 aspartate-282, and tyrosine-254 are located above the flavin $S i$-plane, while Lys-349 stabilizes the negative charge at the flavin position N(1)-C(2) = O (located behind the plane defined by the isoalloxazine ring and below His-373). Adapted with the permission of the authors from [24]<smiles>[Y20]CC[R]([R])(O)C(=O)[O-]</smiles>

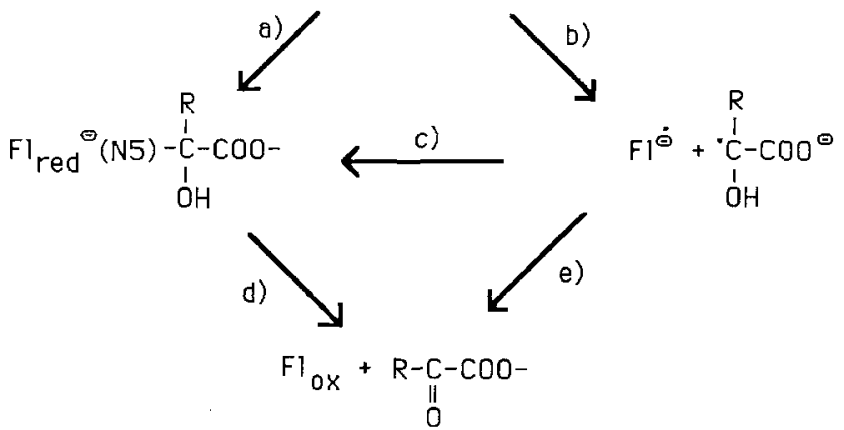

Scheme 1. Alternative modes of transfer of the redox equivalents from carhanionic substrate (a transition state) to the flavin. See text for further details

(a) direct nucleophilic attack at the flavin $\mathrm{N}(5)$ position to yield a covalent adduct; (b) one-electron transfer, followed by (c) collapse of the radical pair to the flavin $\mathrm{N}(5)$-substrate adduct or (e) by a second one-electron transfer to give oxidized substrate and reduced flavin directly; (d) fragmentation of the covalent adduct yields the same products.

In this context the following experimental data are relevant. (a) The reaction of both the above-mentioned enzymes with the normal substrate, L-lactate, is fast and proceeds to the product, pyruvate, without observable intermediates [31, 32]. (b) In the case of glycollate as a substrate, two covalent intermediates are formed with lactate oxidase [18], which are derived respectively from abstraction of either the $R e$ - or the $S i$-proton of the substrate and subsequent addition of the glycollyl moiety to the flavin N(5).

Thus, a covalent adduct lies on a feasible reaction coordinate. Its observation might result simply from the lifetime, i.e. the capacity of the active site to accommodate it and from the thermodynamic difference between adducts of pyruvate and glyoxylate. A differentiation between pathways $(a)$ and $(b+c)$ boils down to semantics if (c) is very fast, as it might be expected to be. Sequence $(b+e)$ might be more feasible for lactate, the difference from glycollate residing in the stability of the two radicals. While the picture presented by Lederer and Matthews is probably an excellent description of the general setup of the active center and of the involvement of a carbanion mechanism for both enzymes, there are some important aspects which we think are incorrect. From simple chemical considerations, the reduced flavin is most unlikely to exist as a dianion with negative charges both at $\mathrm{N}(1)$ and $N(5)$ as proposed in [24]. Placing a strong nucleophile such as the proposed anionic N(5) of reduced flavin at about $370 \mathrm{pm}$ distance to a carbonyl without formation of a $\sigma$ bond appears difficult, especially since with lactate oxidase and glycollate such an adduct is stable. Furthermore His-373 and Tyr-254 could drive the reaction towards adduct formation. The key for the solution might lie in the following telling sentence quoted directly from Lederer and Matthews [24]: '... what strikes immediately is the closeness of His-373 N(3) to the ligand oxygen. It looks as if His-373 were ready to give a proton to an incipient oxyanion arising as the result of hydride donation to substrate $C(2)$ by the reduced flavin'. This description is undoubtedly correct, as well as the deduction. However, as the authors themselves have pointed out, hydride expulsion from $\mathrm{N}(5)-\mathrm{H}$ is unlikely in the present case. A close look at the original figure in question [24] also reveals that, in the context of the above quotation, addition of the lone pair of $\mathrm{N}(5)$ to the substrate $\mathrm{C}(2)$ carbonyl would do exactly the same as a hydride transfer, i.e. produce the expected substrate $\mathrm{C}(2)$ oxyanion via formation of a covalent adduct (Fig. 2). A mechanism such as that proposed in [24] would require that the covalent adducts formed with lactate oxidase and glycollate [18] would be formed in a non-productive side reaction starting from reduced enzyme flavin and glyoxylate. However, the glycollyl adduct derived from abstraction of the $S i$-hydrogen of glycollate clearly has been shown not to be formed directly from reduced enzyme and glyoxylate. Thus either different mechanisms are operative in the two enzymes, or a general one has to be devised, which can also explain the cases of covalent bond formation. We think that the mechanism proposed in Fig. 2 achieves that goal.

$\mathrm{D}$-Amino acid oxidase is another enzyme for which much similar mechanistic evidence exists in favor of a carbanion mechanism [3]. With D-amino acid oxidase the occurrence of a covalent intermediate was first deduced and the corresponding mechanism proposed by Bright and coworkers [22]. A 


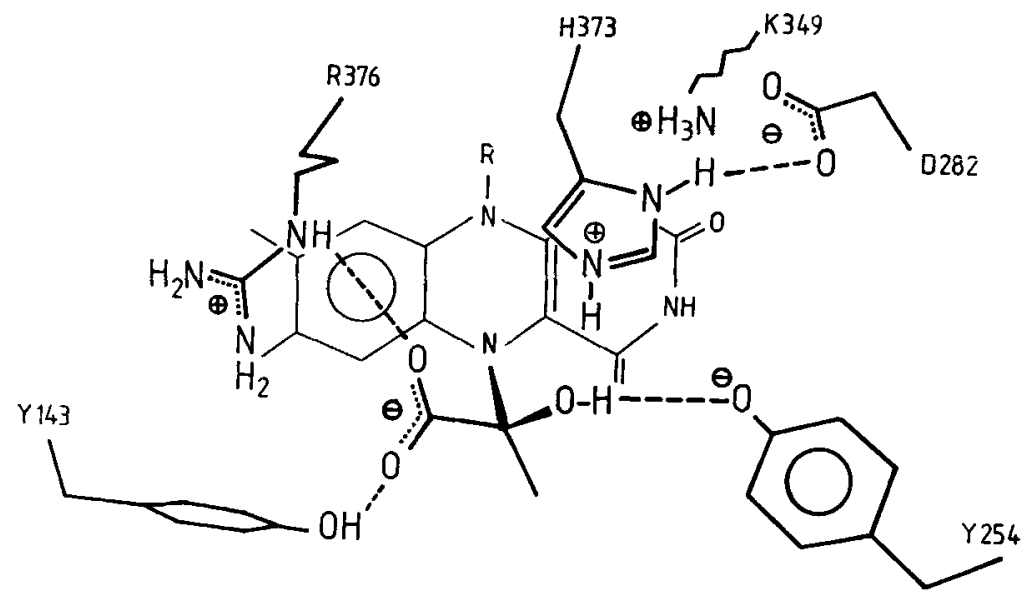

Fig. 2. Active site of yeast L-lactate dehydrogenase (flavocytochrome $\mathrm{b}_{2}$ ), modified from the description of Lederer and Mathews [24] in order to accomodate a covalent adduct between a lactyl residue and the flavin position $N(5)$. This adduct might occur as a transition state during the oxidation of lactate, and an analogous one has been observed upon reaction of lactate oxidase with glycollate. Note that the difference between Figs 1 and 2 is essentially the presence of a covalent bond in the latter, all other interactions being retained, with exception of the charge being on Tyr-254. (Adapted with the permission of the authors [24])

difference from the $\alpha$-hydroxy-acid dehydrogenating enzymes is the $R e$-side specificity of the flavin [26] (Table 1). In addition to the other protein residues believed to play a role in the catalytic reaction (see $[3,33]$ for reviews), a methionine residue located at position 110 in the amino acid sequence has been identified as the residue modified in the inactivation of the enzyme by $\mathrm{O}-(2,4$-dinitrophenyl)hydroxylamine. A possible catalytic role for this residue has been proposed in which it participates in the breakdown of the proposed flavin $\mathrm{N}(5)$ substrate adduct [34].

\section{Substrates undergoing $\alpha, \beta$-dehydrogenation}

The oxidation of acyl-CoA can be viewed as a special case of the dehydrogenation of an 'activated' substrate, the $\alpha$ position of acyl-CoA substrates clearly being activated, the $\beta$ one not. Realizing this, Cornforth suggested in the late fifties a carbanion-initiated mechanism [35], which has been substantiated by several pieces of evidence, as reviewed in detail elsewhere $[3,36]$. The mechanism can thus be formulated as shown in Scheme 2.

Here abstraction of the $\alpha$-hydrogen as a proton is initiated by a protein base, possibly a glutamic acid carboxylate [37, 38]. The substrate has been shown to be positioned on the Reface of the flavin from the stereospecificity studies of Manstein et al. [39]. As pointed out previously, several questions can be asked about the mode of transfer of the redox equivalents from the incipient carbanion to the flavin [36]: do covalent adducts or radical intermediates occur, is the carbanion a true intermediate, as opposed to a transition state, how is the second $\mathrm{C}-\mathrm{H}$ bond broken, e.g. does it occur in a mechanism concerted with rupture of the first $\mathrm{C}-\mathrm{H}$ bond? There are clearcut answers to most of these questions: the reaction proceeds without formation of observable flavin radical or covalent flavin intermediates [38] and the deuterium isotope effects on rupture of the $\alpha$ and of the $\beta$ bond behave multiplicatively as opposed to additively $[40,41]$. This clearly supports a concerted breaking of the two bonds. This mechanism is best reconciled with expulsion of hydride from the $\beta$ position of substrate and its direct addition to the flavin N(5)-position. Indeed studies involving the use of 5-deaza analogs of FAD and general acyl-CoA dehydrogenase confirm this $[39,42]$.
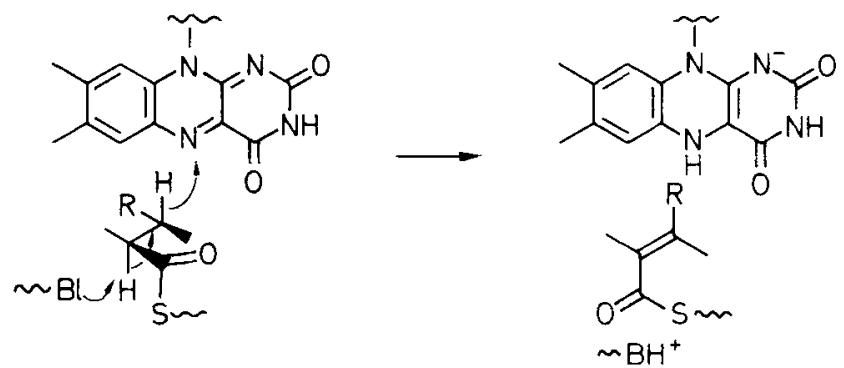

Scheme 2. Mechanism for the concerted rupture of the $C(\alpha)-H$ and $C(\beta)-H$ bonds and concomitant transfer of a hydride to the flavin $N(5)$ position as deduced for general acyl-CoA dehydrogenase. Note that the Re-face of the flavin has been found to accept hydride. Adapted from [42]

On the other hand, several acyl-CoA dehydrogenases have been shown to catalyze exchange at the substrate $\alpha$ position without any reduction occurring or being possible [43], a clear-cut proof that a carbanion can be formed. With some substrates exchange might be concurrent with $\alpha, \beta$-dehydrogenation. This is considered a typical example of an 'uncoupled-concerted' reaction according to the definition of Jencks [44].

General acyl-CoA dehydrogenase from pig kidney is a typical representative of this class of enzymes and it exhibits several noteworthy properties. These include charge transfer absorption bands due to complexation of oxidized enzyme with substrate modifications rendering them good donors, or of reduced enzyme with acceptors such as enoyl-CoA derivatives [45-47]. The enzyme also shows only partial reduction with some substrates and typically exhibits complex kinetics. These phenomena have recently been clarified by a rapidreaction kinetics study [38], as summarized in Scheme 3.

The main point of this scheme is the rationalization of the occurrence of substantial amounts of oxidized enzyme at the end of the reaction even in the presence of excess substrate. This results from the sum of the rates of forward and reverse reactions as well as from the ratios of the $K_{\mathrm{d}}$ for binding of substrate and product to oxidized as well as reduced enzyme. The biphasic reaction course is due to reequilibration of the 


$$
\begin{aligned}
& \mathrm{GAD}_{0}+\mathrm{B}-\mathrm{COA} \stackrel{\mathrm{K}_{\mathrm{d} 1}}{\longleftrightarrow} \mathrm{MC} 1 \underset{\mathrm{K}_{-1}}{\stackrel{\mathrm{K}_{1}}{\rightleftarrows}} \mathrm{I} \underset{\mathrm{k}-2}{\stackrel{\mathrm{K}_{2}}{\rightleftarrows}} \mathrm{MC2} \stackrel{\mathrm{K}_{\mathrm{d} 2}}{\longleftrightarrow} \mathrm{C}-\mathrm{COA}+\mathrm{GAD}_{\mathrm{r}} \\
& k_{4} \uparrow \mid k-4 \mathrm{C}-\mathrm{COA} \\
& \mathrm{GAD}_{\mathrm{O}} * \mathrm{C}-\mathrm{COA} \\
& B-\operatorname{COA} k_{3} \downarrow \uparrow k_{-3} \\
& \mathrm{GAD}_{r} * \mathrm{~B}-\mathrm{CoA}
\end{aligned}
$$

Scheme 3. Kinetic steps involved in the reaction of general acyl-CoA dehydrogenase $\left(G A D_{\mathrm{o}}, G A D_{\mathrm{r}}\right.$ oxidized, reduced forms of the enzyme) with butyryl-CoA $(B-C o A)$ as a substrate. $\mathrm{C}-\mathrm{CoA}=$ crotonyl-CoA, $\mathrm{MC} 1$ and $\mathrm{MC} 2=$ Michaelis complexes formed between oxidized and reduced enzyme and substrate or products. $I=$ intermediate characterized by a pronounced transient charge absorption spectrum above 500 nm. $K_{\mathrm{d} 1}$ and $K_{\mathrm{d} z}$ are the dissociation constants determined for formation of the corresponding complexes and $k_{(1 \text { to-4) }}$ the rates estimated for interconversion of the single species. See text and [38] for details. Adapted from [38]

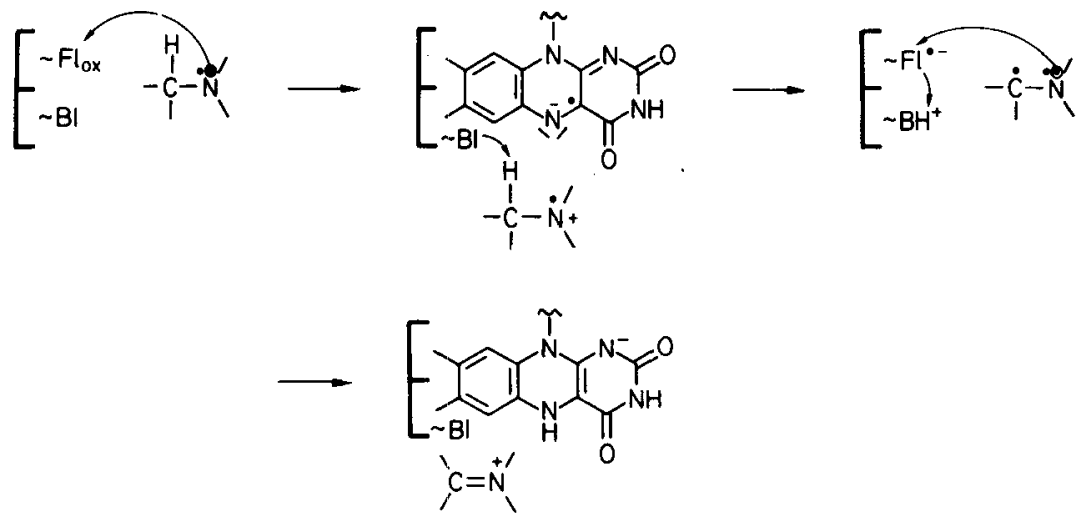

Scheme 4. Mechanism for the oxidation of 'non-activated' amines as proposed by Silverman. (Adapted from [49])

system subsequent to a primary reduction event followed by dissociation of product from the reduced-enzyme-product complex

The enzyme also exhibits an intrinsic (de)hydratase activity which is due to the capacity of the enzyme to abstract a proton reversibly from the $\alpha$ position, thus facilitating expulsion of $\mathrm{HO}^{-}$from the $\beta$ position [48].

\section{Non-activated substrates}

Flavoproteins such as methanol oxidase and monoamine oxidase carry out oxidation of 'non-activated' substrates, this definition meaning the absence of an inductive or mesomeric effect capable of stabilizing formation of a (transient) negative charge. The removal of the $\alpha$-hydrogen as a proton being unlikely to initiate the reaction, several alternatives have been put forward, a plausible one being the radical mechanism formulated by Silverman [49] for monoamine oxidase (Scheme 4).

Mechanistic details such as the sequence of abstraction of $\mathrm{e}^{-}$and of hydrogen have been questioned by Walker and Edmondson, based on the results of a survey of a large number of substrates with catalytic velocities spanning several orders of magnitude, all of which exhibited large primary $(\mathrm{H} / \mathrm{D})$ isotope effects and based on the lack of spectral evidence for flavin semiquinone intermediates [50]. On the other hand, the substituent effects observed on the rates are consistent with a hydrogen atom abstraction in the rate-limiting step [50].

It should be emphasized, however, that there is also no compelling evidence against a hydride transfer mechanism, in particular in the case of alcohol oxidases [51, 52]. With alcohol oxidases, the enzyme is set up in such a way as to strongly stabilize flavin radicals, a hint, that this could reflect stabilization of transition states. Therefore, while we think that a radical mechanism is the most likely, the possibility remains open that oxidation of alcohols and amines might proceed via a hydride transfer mechanism.

These considerations stress the versatility of flavin reactivity, and at the same time make it difficult to reach absolute mechanistic conclusions. Flavins can accept and donate redox equivalents via hydride transfer, radical steps, or formation of covalent adducts. Since in the case of pyridine-nucleotidelinked alcohol dehydrogenases hydride transfer is the accepted mechanism, one might wonder why the same does not apply when the flavin is the acceptor. It might be that the different reaction coordinates are energetically not too dissimilar, and that the better capability of the flavin to stabilize radicals might make the difference.

\section{STEREOSPECIFICITY \\ OF FLAVIN-SUBSTRATE INTERACTIONS}

It has long been recognized that in redox reactions involving pyridine nucleotides, the $\mathrm{H}$ atom involved is transferred stereospecifically, to either the $R e$ - or the $S i$-side of the pyridine ring [53]. With the flavin the same basic situation exists, reactions occurring via the $\mathrm{p}$ orbitals, i.e. on the flavin plane, with the difference that in the general case with $\mathrm{Fl}_{\text {red }} \mathrm{H}^{-}$the side-specific orientation of the hydrogen is easily lost due to exchange of $\mathrm{N}(5)-\mathrm{H}$ or inversion processes at this center. At the active center of proteins, however, exchange and/or inversion can be restricted by the surrounding protein, and access of substrate to the flavin is likely to occur from only one side.

It is thus obvious that similar stereospecificity of substrate flavin interaction involving either the $R e$ - or the $S i$-face of the flavin should exist. This was first shown to be correct for an FMN reductase from luminescent bacteria [54]. From the crystallographic data with glutathione reductase it was clear that pyridine nucleotide was positioned on the $R e$-face of the flavin [9]. This finding has been used as a reference point for 
Table 1. Stereospecificity of flavin-substrate interactions

\begin{tabular}{|c|c|c|c|c|}
\hline Enzyme & Source & Substrate & $\begin{array}{l}\text { Flavin } \\
\text { face }\end{array}$ & $\begin{array}{l}\text { Refer- } \\
\text { ence }\end{array}$ \\
\hline $\begin{array}{l}\text { Glutathione } \\
\text { reductase }\end{array}$ & $\begin{array}{l}\text { human red } \\
\text { blood cells }\end{array}$ & $\mathrm{NADP}^{+}$ & $R e$ & [9] \\
\hline $\begin{array}{l}\text { Mercuric } \\
\text { reductase }\end{array}$ & $\begin{array}{l}\text { Pseudomonas } \\
\text { aeruginosa }\end{array}$ & $\mathrm{NADP}^{+}$ & Re & [39] \\
\hline $\begin{array}{l}\text { Thioredoxin } \\
\text { reductase }\end{array}$ & Escherichia coli & $\mathrm{NADP}^{+}$ & Re & [39] \\
\hline $\begin{array}{c}p \text {-Hydroxy- } \\
\text { benzoate } \\
\text { hydroxylase }\end{array}$ & $\begin{array}{l}\text { Pseudomonas } \\
\text { fluorescens }\end{array}$ & $\mathrm{NADP}^{+}$ & $R e$ & {$[39]$} \\
\hline $\begin{array}{l}\text { Melilotate } \\
\text { hydroxylase }\end{array}$ & $\begin{array}{l}\text { Pseudomonas } \\
\text { sp. }\end{array}$ & $\mathrm{NADP}^{+}$ & $R e$ & [39] \\
\hline $\begin{array}{l}\text { Anthranilate } \\
\text { hydroxylase }\end{array}$ & $\begin{array}{l}\text { Trichosporum } \\
\text { cutaneum }\end{array}$ & $\mathrm{NADP}^{+}$ & $R e$ & [39] \\
\hline $\begin{array}{l}\text { 2-Methyl-3- } \\
\text { hydroxy- } \\
\text { pyridine-5- } \\
\text { carboxylic } \\
\text { acid oxygenase }\end{array}$ & $\begin{array}{l}\text { Pseudomonas } \\
\text { sp. }\end{array}$ & $\mathrm{NADP}^{+}$ & $R e$ & {$[26]$} \\
\hline $\begin{array}{l}\text { Cyclohexanone } \\
\text { monooxygenase }\end{array}$ & Acinetobacter & $\mathrm{NADP}^{+}$ & $R e$ & [26] \\
\hline Glucose oxidase & $\begin{array}{l}\text { Aspergillus } \\
\text { niger }\end{array}$ & glucose & $\operatorname{Re}$ & [39] \\
\hline $\begin{array}{c}\text { General acyl-CoA } \\
\text { dehydrogenase }\end{array}$ & pig kidney & $\begin{array}{l}\text { enoyl-CoA } \\
\mathrm{BH}_{4}\end{array}$ & $\operatorname{Re}$ & [39] \\
\hline $\begin{array}{l}\text { D-Amino acid } \\
\text { oxidase }\end{array}$ & pig kidney & $\begin{array}{l}\text { pyruvate } \\
+\mathrm{NH}_{3}^{+}\end{array}$ & $R e$ & {$[26]$} \\
\hline $\begin{array}{l}\text { L-Lactate } \\
\text { oxidase }\end{array}$ & $\begin{array}{l}\text { Mycobacterium } \\
\text { smegmatis }\end{array}$ & pyruvate & Si & [26] \\
\hline $\begin{array}{l}\text { D-Lactate } \\
\text { dehydrogenase }\end{array}$ & $\begin{array}{l}\text { Megasphera } \\
\text { elsdenii }\end{array}$ & pyruvate & Si & [26] \\
\hline $\begin{array}{c}\text { Glycollate } \\
\text { oxidase }\end{array}$ & spinach & $\begin{array}{l}\text { thioglycollate } \\
\text { (inhibitor) }\end{array}$ & $S i$ & {$[25]$} \\
\hline $\begin{array}{l}\text { Flavocyto- } \\
\text { chrome } b_{2}\end{array}$ & yeast & pyruvate & Si & [24] \\
\hline
\end{tabular}

determining flavin-substrate stereospecificity in other flavoproteins, using 5-deaza-8-hydroxyflavins as replacements of the native flavin, and determining the stereospecificity of ${ }^{3} \mathrm{H}$ transfer between the reduced deazaflavin and substrate relative to that with glutathione reductase [26, 39]. Knowledge of flavin-substrate stereospecificity available to date is summarized in Table 1 . Of the eight pyridine-nucleotidelinked flavoproteins so far tested, all use the flavin $R e$-face in their interaction with pyridine nucleotides. In other replacement studies involving flavins with chemically reactive substituents, the same enzymes all showed that the flavin benzene ring was exposed to solvent [7]. With the two pyridinenucleotide-linked flavoproteins whose crystal structures have been determined (glutathione reductase [9] and $p$ hydroxybenzoate hydroxylase [10]) there is a clear channel leading from the exposed benzene ring of the flavin along its $R e$-face; it is through this channel that the pyridine nucleotide gains access to the flavin. Thus it would appear that all these enzymes have common structural features, suggesting a common evolutionary pathway. It should be noted, however, that approximately half the flavoenzymes tested remove the $S$ proton from NAD(P)H and half the $R$-proton [55].

\section{FLAVOENZYMES CONTAINING}

A REDOX-ACTIVE DISULFIDE

An interesting group of flavoenzymes about which much mechanistic and structural information is available is one where a redox-active cystine residue of the protein acts in concert with the flavin to carry out the catalytic reaction. This group of enzymes has a common theme of structural elements, modulated from one enzyme to the other in order to accommodate the particular catalytic task. The group includes lipoyl dehydrogenase, glutathione reductase, thioredoxin reductase, trypanothione reductase and mercuric reductase. Early work on the first three enzymes has been described in detail in a review by Williams [56].

With the exception of thioredoxin reductase, which appears to have a quite different protein structure, there are remarkable similarities between the other known enzymes of the group, one of the most notable characteristics of which is the absorption spectrum of the $2 \mathrm{e}^{-}$-reduced enzyme, which lead to the discovery of the redox-active disulfide in lipoyl dehydrogenase $[57,58]$ and glutathione reductase [59]. In this $\mathrm{EH}_{2}$ form the flavin is oxidized, the disulfide reduced, and the long-wavelength absorption is due to charge transfer between the thiolate anion of one of the nascent cysteine residues and the oxidized flavin $[60-62]$. The other remarkable similarity between the enzymes is that of similar amino acid sequence [63-66] and chain folding, resulting in overall similar three-dimensional structures. In the case of glutathione reductase from human erythrocytes, the three-dimensional structure has been solved by X-ray diffraction to $0.2-\mathrm{nm}$ resolution $[67,20]$ and recently refined to $0.154-\mathrm{nm}$ resolution [68]. Thus this structure has become the prototype for ideas about most of the other enzymes of the group. As will be described later, this approach has been very successful, particularly for mercuric reductase, but clearly has to be done with caution, because the enzymes are after all distinctly different species as shown by the very different behavior of the 6-SCN derivative of FAD introduced into glutathione reductase [69] and mercuric reductase [70]. Fortunately the crystal structures of a lipoyl dehydrogenase from Azotobacter vinelandii [71] and the plasmid-encoded Escherichia coli mercuric reductase (E. F. Pai, personal communication) are under active investigation, so that conjecture may soon be replaced by fact. Similarly the recent cloning of the genes for $E$. coli and $A$. vinelandii lipoyl dehydrogenase [73, 74] and for Pseudomonas aeruginosa glutathione reductase [75] and the site-directed mutagenesis work, which is underway, will do much to clarify similarities and differences within the group. (Extensive gene manipulation has already been performed with mercuric reductase, see later section.)

\section{Glutathione reductase}

The steps involved in the reaction catalyzed by glutathione reductase:

$$
\mathrm{GSSG}+\mathrm{NADPH}+\mathrm{H}^{+} \rightleftharpoons \mathrm{NADP}^{+}+2 \mathrm{GSH}
$$

had been dissected in some detail with the yeast enzyme by a combination of classical spectroscopic and rapid-reaction techniques $[59,76-78]$ and by specific chemical modifications $[79,80]$. The reaction mechanism proposed for the yeast enzyme was confirmed in exquisite detail by the structural studies on the human erythrocyte enzyme, where the locations of the NADPH and glutathione substrates were easily determined, as well as the location and probable role of specific active-site residues $[20,67]$.

Fig. 3 is a cartoon representation of the active site, showing the location of the FAD prosthetic group, the activesite disulfide (Cys-58 - Cys-63), the positions for binding of $\mathrm{NADPH}$ and GSSG, and the location of several residues 


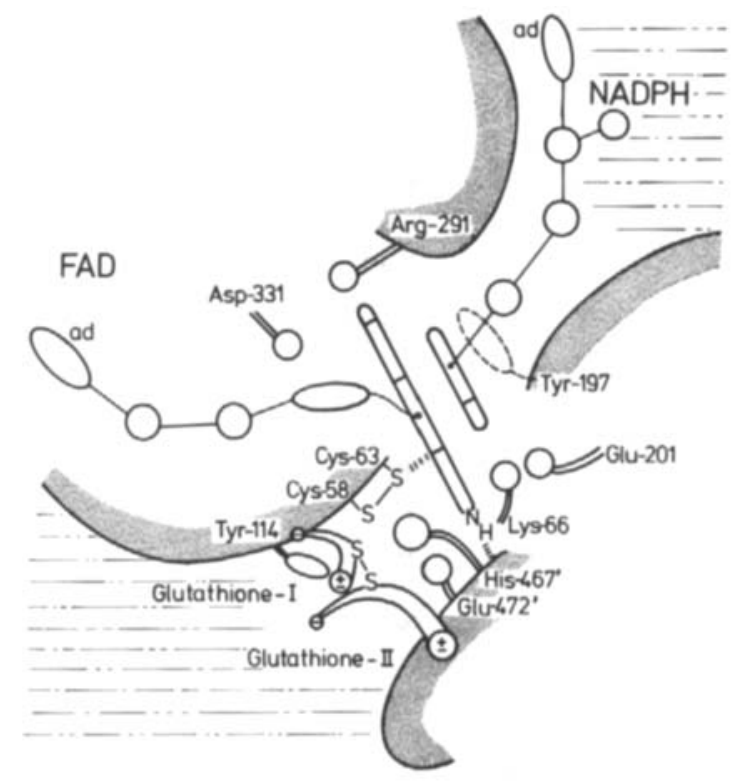

Fig. 3. A cartoon representation of the catalytic center of glutathione reductase as described in [20] by Schulz and Pai. Obtained from the authors and reproduced with their permission

believed to be important in catalysis [20]. A noteworthy feature of the active site is that it is made up of components from the two separate but identical polypeptide chains of the dimeric protein molecule, i.e. there are two identical active sites, in each case a GSSG is bound by elements of the two separate polypeptide chains, and the His-467' and Glu-472' residues shown are located in the polypeptide chain which contributes the Cys-58 - Cys-63 pair to the second active site.

Considering catalysis in the predominant physiological direction:

$$
\mathrm{GSSG}+\mathrm{NADPH}+\mathrm{H}^{+} \rightarrow \mathrm{NADP}^{+}+2 \mathrm{GSH}
$$

the following steps are envisaged or, in many cases, found to occur $[20,80,81]$.

a) Binding of NADPH involves a conformational change in which Tyr-197, normally in the position shown by the dotted line in Fig. 3, is displaced to allow entrance of the pyridine nucleotide so that the dihydropyridine ring is positioned roughly parallel to the flavin and on its $R e$-face [67].

b) The $\mathrm{C}(4)$ atom of the pyridine nucleotide lies directly above the flavin $N(5)$ at a distance of $0.35 \mathrm{~nm}$. Thus the $4 S$ hydrogen of NADPH should be positioned correctly for hydride transfer to flavin-N(5). Independent evidence for such a specific transfer comes from experiments where the native FAD was replaced with the 8-hydroxy-5-deaza derivative of FAD, and where stereospecific transfer of ${ }^{3} \mathrm{H}$ label between reduced flavin and pyridine nucleotide was shown [39].

c) The next step is envisaged to be reduction of the activesite disulfide (which is located on the Si-side of the flavin ring) by the anionic reduced flavin, via a labile flavin C(4a)cysteinyl linkage. Precedence for such an intermediate comes from observations on the effect of $\mathrm{NAD}^{+}$on the EHR form of lipoyl dehydrogenase (where the active-site thiol closest to the N-terminus was alkylated by reaction with iodoacetamide) [82]. This step is accompanied by or rapidly followed by uptake of $\mathrm{H}^{+}$from a bound $\mathrm{H}_{2} \mathrm{O}$ molecule [68] by a protein base, presumably His-467. d) Following breakage of the labile flavin C(4)-cysteinyl bond the flavin is returned to the normal oxidized state, the disulfide being reduced, with Cys-58 protonated and Cys-63 as the thiolate anion. The Cys- 63 thiolate was shown to be the one responsible for the charge-transfer absorption as alkylation of Cys-58 does not affect the charge-transfer interaction [80]. Titration of the thiolate results in loss of the chargetransfer absorption with a $\mathrm{p} K$ of 4.8 [80]. The formation of this species is accompanied by the rapid release of $\mathrm{NADP}^{+}$ to form free $\mathrm{EH}_{2}$. The proposed sequence of reactions 3 and 4 is shown in Scheme 5. The structure of $\mathrm{EH}_{2}$ (Scheme 5, structure III) has been determined in crystal-soaking experiments, where the sulfur of Cys-58 was found to move closer to the GSSG binding site by approximately $0.1 \mathrm{~nm}$, while there was also a slight movement $(\approx 0.01 \mathrm{~nm})$ of Cys-63 toward the flavin [20].

e) The series of reactions described above constitute the reductive half of the catalytic reaction and are very rapid [59, 78, 79]. The catalytic cycle is completed by the reaction of $\mathrm{EH}_{2}$ with GSSG, via thiol-disulfide interchange reactions, as envisaged in Scheme 6.

In this sequence the tautomeric form of $\mathrm{EH}_{2}$ shown in structure IV is envisaged as the nucleophile attacking the disulfide of bound GSSG to liberate GSH and forming the mixed Cys-58 -S-S-G disulfide of form V [80]. The structure of the latter species has again been determined by X-ray diffraction in crystal-soaking experiments and confirmed that Cys- 58 was indeed the residue involved in the thiol-disulfide interchange reaction [20]. This had been predicted from the chemical modification studies, where it was shown that iodoacetamide alkylated Cys- 58 preferentially by a factor of approximately 10 , and that the resulting EHR was stable to oxidation by $\mathrm{O}_{2}$, ferricyanide or GSSG [80]. Similarly, in crystal-soaking experiments, no evidence was found for binding of GSSG to EHR [20]. The remaining step in the catalytic cycle shown in Scheme 6 involves the nucleophilic attack of the thiolate of Cys-63 on the mixed disulfide of state V. In a reaction which is probably concerted with deprotonation of His- $467^{\prime}$, the second molecule of protonated GSH is liberated, returning the enzyme to its fully oxidized state, ready for the next catalytic cycle.

\section{Lipoyl dehydrogenase}

As discussed previously by Thorpe et al. [80] and Matthews et al. [83,84], a set of reactions analogous to those described in Schemes 5 and 6 for glutathione reductase can be formulated for lipoyl dehydrogenase; in fact many of the mechanistic concepts found to apply for glutathione reductase were first formulated in studies with lipoyl dehydrogenase. These included the nature of $\mathrm{EH}_{2}[57,58]$, the recognition of an active-site base forming an ion pair to stabilize the thiolate anion of $\mathrm{EH}_{2}$ and to play its catalytic role in the thiol-disulfide interchange reaction with lipoic acid and lipoyl derivatives [62] and the recognition that the two cysteines of the active site play distinct roles in the catalytic cycle [81]. One apparently different property is that while alkylation of Cys-58 in glutathione reductase has no effect on the chargetransfer absorption of $\mathrm{EH}_{2}$ [24], the reaction of iodoacetamide with the analogous thiol of lipoyl dehydrogenase (Cys-45) to form EHR, abolishes the charge-transfer interaction between the thiolate of Cys-50 and oxidized FAD [81]. This is probably due to a distortion of the active-site geometry brought about by the alkyl substituent and could be a reflection of the relative sizes of the enzyme pockets binding the disulfide substrate in 

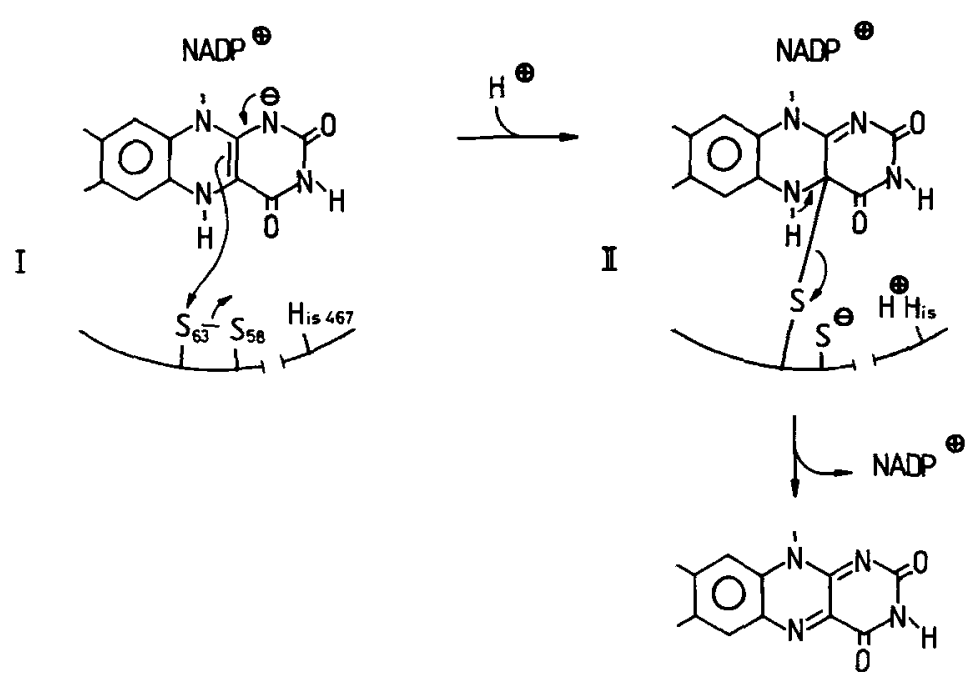

III

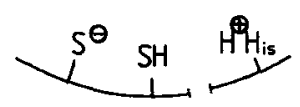

Scheme 5. Interaction between reduced flavin and the redox-active disulfide at the active site of glutathione reductase

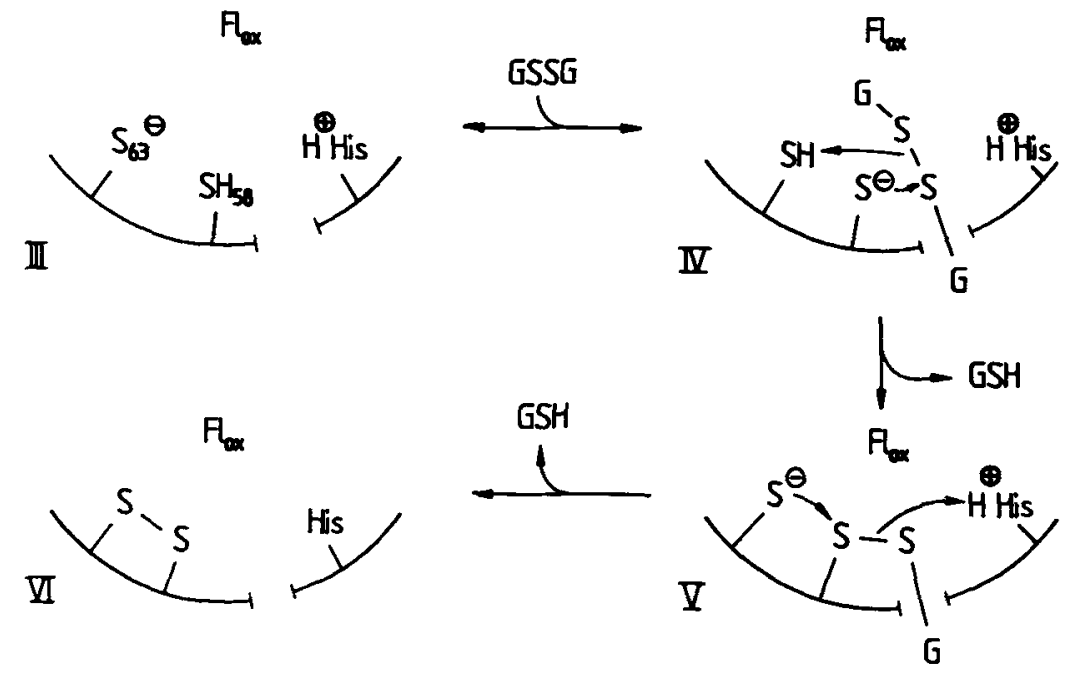

Scheme 6. Mode of reduction of axidized glutathione at the active center of glutathione reductase showing the thiol-disulfide interchange reactions involved in catalysis. See text for details

the two enzymes, there being sufficient room to accomodate the alkyl group in the rather large GSSG-binding pocket of glutathione reductase without disturbing the orientation of Cys-63 with respect to the flavin, but not in the analogous case of lipoyl dehydrogenase [80].

\section{Trypanothione reductase}

A recent finding of potential world health significance is that trypanosomes and other protozoal parasites do not possess glutathione reductase, but instead a closely related enzyme with no activity toward glutathione, but with high activity toward the glutathione conjugate trypanothione disulfide $\left[N^{1}, N^{8}\right.$-bis(glutathionyl)-spermidine disulfide] [85]. The enzyme has been isolated from Crithidia fasciculata [86] and Trypanosoma cruzi [87] and shown to have very similar properties to those of glutathione reductase, including molec- ular mass, non-covalently bound FAD, an active-site disulfide with 14 residues identical with glutathione reductase, the formation of a typical $\mathrm{EH}_{2}$ charge-transfer spectrum and specific alkylation of $\mathrm{EH}_{2}$ with iodoacetamide at the active-site cysteine closest to the $\mathrm{N}$-terminus $[86,87]$. While little structural or mechanistic work has yet been reported, the reaction mechanism is undoubtedly similar to that of glutathione reductase.

\section{Mercuric reductase}

Mercuric reductase catalyzes the reduction of $\mathrm{Hg}(\mathrm{SR})_{2}$ to $\mathrm{Hg}^{0}$ using NADPH as reductant; added thiols are required for efficient catalysis, so that the overall reaction may be written:

$$
\mathrm{Hg}(\mathrm{SR})_{2}+\mathrm{NADPH}+\mathrm{H}^{+} \rightarrow \mathrm{Hg}^{0}+2 \mathrm{RSH}+\mathrm{NADP}^{+} .
$$


The enzyme was found to contain a redox-active cystine residue, in analogy to lipoyl dehydrogenase and glutathione reductase [88]. It also exhibited a spectrum on $2 \mathrm{e}^{-}$reduction which was remarkably similar to the $\mathrm{EH}_{2}$ spectra of lipoyl dehydrogenase and glutathione reductase and, like the latter, could be converted to an EHR form with iodoacetamide which still retained the charge-transfer absorbance [89]. It was thus evident that remarkable similarities in structure must exist between these enzymes; this was borne out by the finding that the sequences of the active-site tryptic peptide from EHR were identical for 11 and 12 of the 16 residues of the activesite peptides of pig heart lipoyl dehydrogenase and human erythrocyte glutathione reductase respectively [89]. Further rapid progress with this enzyme was made possible by the cloning and sequencing of the gene encoding the enzyme and the demonstration of extensive sequence similarities with the other enzymes of the group [66]. Thus it was clear by analogy that the active-site disulfide should comprise residues Cys135 and Cys-140, and that the latter should be the group responsible for the charge-transfer absorption of the $2 \mathrm{e}^{-}$reduced enzyme. This was shown directly in elegant studies of Schultz et al. [90], where two oligonucleotide-directed mutant enzymes were constructed, Ser-135/Cys-140 and Cys-135/Ser140. As expected, both of these enzymes lacked mercuric reductase activity, but retained NADPH transhydrogenase activity. The Cys-135/Ser-140 enzyme showed a normal flavin absorption spectrum and was reduced fully by uptake of twoelectron equivalents to the $\mathrm{FADH}_{2}$ form with no intermediate charge-transfer absorption. On the other hand, the Ser-135/ Cys-140 enzyme exhibited charge-transfer absorption in the oxidized state; on lowering the $\mathrm{pH}$, the long-wavelength absorbance decreased and the spectrum became like that of normal flavin [90]. These results demonstrated very beautifully that Cys-140 was indeed the thiolate residue in chargetransfer interaction with the flavin, with a $\mathrm{p} K$ of 5.2. A large number of other mutant forms of the enzyme have been constructed to answer specific questions of structure and mechanism [91 -93]. Lack of space prevents us describing this work in detail, but it should be mentioned that the changes not only in catalytic properties but also in other physicochemical characteristics of the enzyme flavin, such as absorption spectrum, fluorescence and redox potential which are induced by single amino acid replacements, provide a wealth of information concerning the importance of specific flavin - protein interactions.

Like lipoyl dehydrogenase [84] and glutathione reductase [77], the absorption spectrum of the $\mathrm{EH}_{2}$ form of mercuric reductase is also influenced by complex formation with $\mathrm{NADP}^{+}$and NADPH. The spectra of $\mathrm{EH}_{2} \cdot \mathrm{NADP}^{+}$and $\mathrm{EH}_{2}$ - NADPH are differentiated by the latter having appreciably greater absorbance in the $510-560-\mathrm{nm}$ region, while $\mathrm{EH}_{2} \cdot \mathrm{NADP}^{+}$has greater absorbance than $\mathrm{EH}_{2} \cdot \mathrm{NADPH}$ at wavelengths beyond $580 \mathrm{~nm}$. These characteristics were initially discovered in rapid-scanning stopped-flow experiments studying the reductive half of the reaction with NADPH as the substrate, where the sequence shown below can be inferred [94]:

$$
\begin{gathered}
\mathrm{E}+\mathrm{NADPH} \stackrel{k_{1}}{\rightleftharpoons} \mathrm{E}-\mathrm{NADPH} \stackrel{k_{2}}{\rightarrow} \mathrm{EH}_{2}-\mathrm{NADP}^{+} \\
\mathrm{EH}_{2}-\mathrm{NADP}^{+} \stackrel{k_{3}}{\rightleftharpoons} \mathrm{EH}_{2}+\mathrm{NADP}^{+} \\
\mathrm{EH}_{2}+\mathrm{NADPH} \stackrel{k_{4}}{\rightleftharpoons} \mathrm{EH}_{2}-\mathrm{NADPH} .
\end{gathered}
$$

In this study, at $\mathrm{pH} 7.3,5^{\circ} \mathrm{C}$, E-NADPH (presumably a charge-transfer complex with NADPH as donor and FAD as acceptor, and preceding reduction) was formed in the dead time of the stopped-flow apparatus, with $\mathrm{EH}_{2}-\mathrm{NADP}^{+}$and $\mathrm{EH}_{2}-\mathrm{NADPH}$ following sequentially at rates of $43 \mathrm{~s}^{-1}$ and $8 \mathrm{~s}^{-1}$, independent of the NADPH concentration. The latter rate is probably determined by the 'off' constant, $k_{3}$. Further rapid-reaction experiments monitoring the enzyme spectrum during catalytic turnover with $\mathrm{Hg}$ (cysteine $)_{2}$ and NADPH as the limiting substrate indicated that the enzyme was predominantly in the $\mathrm{EH}_{2}-\mathrm{NADPH}$ form in the steady state [95] in agreement with the conclusions of Miller et al. [96].

The mutant enzyme studies have shown that the N-terminal cysteine residues, Cys-10 and Cys-13, do not appear to play any catalytic role [91]. On the other hand, when the C-terminal cysteine pair, Cys-558-Cys-559 is replaced by alanine residues, mercuric reductase activity is lowered drastically, by a factor of approximately 1000 [92]. The C-terminal cysteines have been shown by fluorescence studies to be located close to the flavin and to be in slow redox communication with the active-site Cys-135-Cys-140 pair. Thus, on storage at $0^{\circ} \mathrm{C}$ for several days, it is found that the flavin fluorescence of wild-type enzyme is approximately double that when the enzyme is freshly isolated, and that this is due to the oxidation of the Cys-558 - Cys-559 pair to the disulfide [97]. In this form the enzyme exhibits a lag in mercuric reductase activity (see also [98]), due to the necessity of reducing the $\mathrm{C}$-terminal disulfide via the active-site dithiol. The oxidized enzyme, with Cys-558 - Cys-559 as disulfide, on anaerobic titration with NADPH or dithionite gives rapid spectral changes indicative of $\mathrm{EH}_{2}$ formation on each addition of reducing agent, followed by slower disappearance of the longwavelength absorption. Spectra taken at equilibrium after each addition show that full formation of $\mathrm{EH}_{2}$ is not achieved until $1.8 \mathrm{~mol}$ dithionite is added/mol enzyme flavin; formation of $\mathrm{EH}_{4}$ requires $3 \mathrm{~mol}$ dithionite/mol. In contrast, enzyme which has been pre-treated with dithiothreitol, and then filtered through Sephadex G-25 to remove excess reagent (the active-site disulfide is reoxidized during this step), requires only one equivalent of dithionite to be reduced to the $\mathrm{EH}_{2}$ level (or one equivalent of NADPH to reach the $\mathrm{EH}_{2}-\mathrm{NADP}^{+}$ level) and shows no lag in catalysis [97]. Rapid-reaction studies showed that the thiol-disulfide interchange between Cys135 - Cys-140 and Cys-558-Cys-559 is too slow to be involved as a catalytic step, rather the reduction of the $\mathrm{C}$-terminal disulfide is a necessary priming step for catalysis.

The catalytic role of the C-terminal cysteine pair was suggested by rapid-reaction studies of the mutant enzyme Ala558 -Ala-559 [99]. Reaction of the enzyme with an equimolar concentration of $\mathrm{HgCl}_{2}$-EDTA and an excess of NADPH lead to the rapid production of $\mathrm{EH}_{2}-\mathrm{NADPH}$, as with wild-type enzyme, followed by slower conversion $\left(k \approx 2 \mathrm{~s}^{-1}\right.$ at $\mathrm{pH} 7.3$, $\left.4^{\circ} \mathrm{C}\right)$ to an inhibited enzyme with a strong charge-transfer interaction between NADPH and oxidized flavin, which is quite distinct from the $\mathrm{EH}_{2}$ forms of the enzyme. As the complex requires only one equivalent of $\mathrm{Hg}^{2+}$, it is clear that no reduction of $\mathrm{Hg}^{2+}$ had occurred and that probably the inhibited form involves complexing of $\mathrm{Hg}^{2+}$ with both the active-site thiols, Cys-135 and Cys-140. The role of Cys-558Cys-559 in catalysis can therefore be envisaged as essential for efficient binding of $\mathrm{Hg}^{2+}$ without formation of an inhibited complex like that described above, involving a bidentate complex with Cys-135-Cys-140. Such bidentate complexes typically have association constants in the range of $K_{\mathrm{a}}$ $=10^{37}-10^{45}[100,101]$ and would be expected to lower the 
redox potential of the bound $\mathrm{Hg}^{2+}$ to such a level (as low as $-475 \mathrm{mV}$ ) as to be thermodynamically difficult to reduce by NADPH. Thus it has been proposed that the C-terminal cysteine residues participate with the active-site thiol pair to provide a tri- or tetra-coordinate $\mathrm{Hg}^{2+}$ complex at the active site [97]. With the additional ligands to $\mathrm{Hg}^{2+}$, the resulting complex should be energetically destabilized relative to the bidentate complex, primarily due to unfavorable interactions between ligand electrons and those on $\mathrm{Hg}^{2+}$. Thus, each of the $\mathrm{Hg}-\mathrm{S}$ bonds in the complex should be more ionic in character, with more positive charge being localized on the $\mathrm{Hg}^{2+}$, than in the bidentate complex and hence have a higher and more favorable reduction potential. It should be noted that Brown and coworkers, comparing the sequence homology between mercuric reductase and glutathione reductase, suggested that the $\mathrm{C}$-terminal cysteine pair might be involved in $\mathrm{Hg}^{2+}$ binding [66]. Their proposal derived from the assumption that the two proteins are likely to fold in a similar fashion. Since glutathione reductase has the $\mathrm{C}$-terminal of one monomer folded into the active site of the other monomer in order to provide the catalytically essential histidine residue (see previous section), it seemed reasonable to propose that in mercuric reductase the $\mathrm{C}$-terminal cysteines of one subunit may be similarly folded into the active site of the other subunit.
A
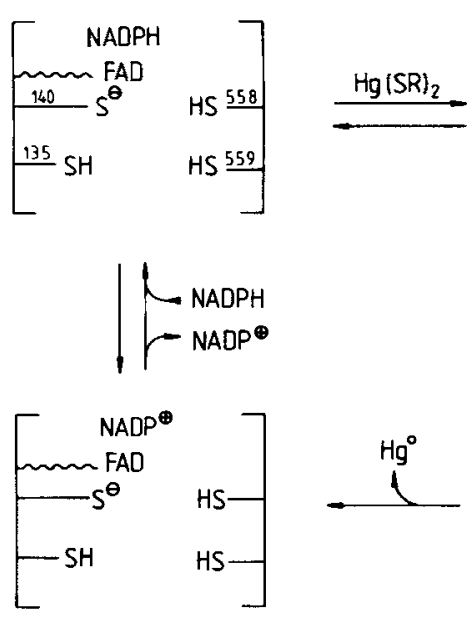

D
B
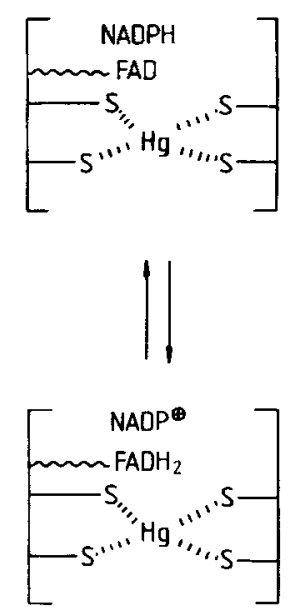

C
Scheme 7. Role of the C-terminal cysteine pair, Cys-558 and Cys-559, in conjunction with the active-site cysteine pair, Cys-135 and Cys-140, to form a multidentate complex with $\mathrm{Hg}^{2+}$, and the subsequent reduction of $\mathrm{Hg}^{2+}$ to $\mathrm{Hg}$. From [97]
This prediction was thus borne out very nicely by the later findings.

The proposed role of the C-terminal thiols in the catalytic mechanism is illustrated in Scheme 7. The $\mathrm{EH}_{2}-\mathrm{NADPH}$ complex of activated enzyme (form $\mathrm{A}$ ) is produced, as described earlier, by reaction of 3 mol NADPH with 1 mol unactivated enzyme or $2 \mathrm{~mol}$ NADPH with $1 \mathrm{~mol}$ pre-activated enzyme. Binding of $\mathrm{Hg}^{2+}$ results in a tri- or tetra-coordinate complex (form B). As discussed above, this would be expected to raise the redox potential of the bound $\mathrm{Hg}^{2+}$ so that it might be readily reducible by the reduced flavin of form $\mathrm{C}$. The dissociation of $\mathrm{Hg}^{0}$ would thus result in the activated $\mathrm{EH}_{2}^{-}$ $\mathrm{NADP}^{+}$complex (form D), which by dissociation of NADP and reaction with NADPH would complete a catalytic cycle [97]. This scheme is a modification of that proposed by Miller et al. [96], to take into account not only the role of the C-terminal cysteines, but also the observations of Distefano et al. [93] for the reduction of $\mathrm{Hg}^{2+}$ by reduced flavins. Although the mechanism of reduction of $\mathrm{Hg}^{2+}$ is not yet clear, the most likely route, in analogy with the mechanisms of glutathione reductase and lipoyl dehydrogenase, would be via a transitory C(4a) adduct of the flavin with Cys-140, concomitant with an outer-sphere reduction of $\mathrm{Hg}^{2+}$, as shown in Scheme 8. Experimental support for this mechanism comes from rapid-reaction studies of wild-type enzyme with NADPH at low $\mathrm{pH}$ values (but in the absence of $\mathrm{Hg}^{2+}$ ) where spectral changes consistent with the intermediate formation of a flavin C(4a) derivative were observed [102].

In summary, the presence of the C-terminal cysteine pair in mercuric reductase appears to be the main factor differentiating this enzyme from lipoyl dehydrogenase and glutathione reductase, and permitting the efficient reduction of $\mathrm{Hg}^{2+}$ as opposed to reduction of disulfide substrates with the other enzymes. It should be noted that the $\mathrm{EH}_{2}$ forms of both lipoyl dehydrogenase [103] and glutathione reductase [59] react with $\mathrm{Hg}^{2+}$, but form inhibited complexes, probably due to formation of tight bidentate complexes with the activesite thiols. In the absence of the C-terminal cysteine pair, mercuric reductase is restricted in catalytic capacity in ways similar to those of the disulfide reductases, i.e. to transhydrogenation reactions, which involve only the flavin, and to thiol-disulfide interchange reactions, such as NADPH $\mathrm{Nbs}_{2}$ reductase activity [93].

\section{ELECTRON TRANSFER MECHANISMS}

Reduced flavoproteins, produced by the pathways described in the previous sections, can complete their catalytic cycle in the oxidative half-reaction, either by one- or twoelectron transfers. We have already discussed in some detail

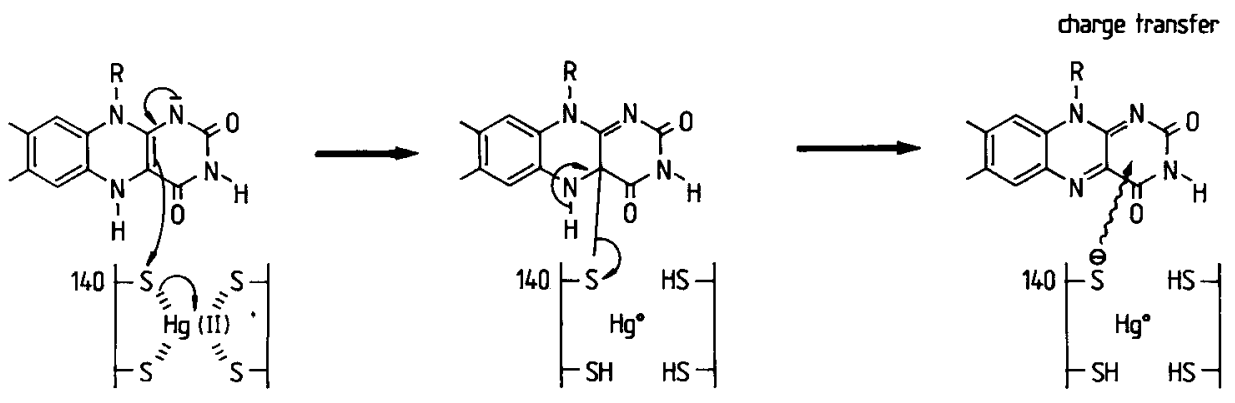

Scheme 8. Detailed catalytic mechanism proposed for the reduction of $\mathrm{Hg}^{2+}$ at the active center of mercuric reductase. From [97] 
the oxidative half-reaction in the case of flavoproteins also having a redox-active disulfide, because in these enzymes the definition of what constitutes the reductive and what the oxidative half-reaction is rather arbitrary, since the reactions are in general quite reversible, and involving two-electron transfer steps. In the final section we will deal with the reaction of reduced flavins and flavoproteins with molecular oxygen, because of the complexities of these reactions and the large number of enzymes involved. In this section we will discuss briefly one-electron transfers involving flavins. The crossover between two-electron transfers, catalyzed by simple pyridinenucleotide-linked enzymes, and the one-electron transfers, occurring with iron-sulfur proteins and heme proteins, is a phenomenon largely restricted to flavoproteins and quinones and is due to their favorable redox potentials and thermodynamic stabilization of the semiquinone forms.

At first sight it might appear to be relatively simple to reoxidize a reduced flavoprotein in two sequential steps, a process which must exist for example with enzymes which use ferricyanide as a good acceptor:

$$
\begin{gathered}
\mathrm{E}-\mathrm{Fl}_{\mathrm{red}} \mathrm{H}_{2}+\mathrm{Fe}(\mathrm{CN})_{6}^{3-} \rightarrow \mathrm{E}-\mathrm{FlH}+\mathrm{Fe}(\mathrm{CN})_{6}^{4-} \\
\mathrm{E}-\mathrm{FlH}+\mathrm{Fe}(\mathrm{CN})_{6}^{3-} \rightarrow \mathrm{E}^{-} \mathrm{Fl}_{\mathrm{ox}}+\mathrm{Fe}(\mathrm{CN})_{6}^{4-} .
\end{gathered}
$$

Such a simple two-step mechanism was first documented by Strittmatter in the case of NADH - cytochrome $b_{5}$ reductase, who showed that the fully reduced enzyme and its semiquinone form were able to reduce cytochrome $b_{5}$ at rates sufficiently high to be consistent with steady-state turnover [104]. A similar two-step mechanism has been demonstrated for reaction between reduced general acyl-CoA dehydrogenase and the electron-transferring flavoprotein of pig kidney [105]. In this case the electron transfer was shown to be rapid only when the enoyl-CoA product was bound to the reduced dehydrogenase, thus identifying the important role of the product in modulating the thermodynamic and kinetic behavior of the dehydrogenase.

The factors governing such electron transfers between two proteins have been explored in a series of rapid reaction studies by Tollin and coworkers, employing the photogenerated flavodoxin semiquinone as reductant and a number of heme proteins and ferric salts as oxidants [106-108]. The rates of electron transfer were concluded to be determined by contributions from three main factors, the thermodynamic driving force between the two partners, protein surface topography and electrostatic potential at the reaction site. Computer modelling showed a very nice fit between the negatively charged region of the protein around the flavin semiquinone and a positively charged region around the heme edge of cytochrome $c[106-108]$, suggesting that this interaction was important for the electron transfer process, and consistent with the observed effects of ionic strength on the reaction rate. This was supported by the opposite effect of increasing ionic strength causing an increased rate of electron transfer to ferricyanide, consistent with a kinetic barrier between two negatively charged partners [106].

A clear limitation on the use of two sequential one-electron transfers in enzyme catalysis would be if the reaction of the flavoprotein semiquinone with the one-electron oxidant was much slower that the first one-electron transfer. A good example of this is given by flavodoxin: while the fully reduced protein at $\mathrm{pH} 7,25^{\circ} \mathrm{C}$ reacts with molecular oxygen relatively fast to yield the flavodoxin neutral semiquinone and $\mathrm{O}_{2}^{-}$ $\left(k \approx 10^{4} \mathrm{M}^{-1} \mathrm{~s}^{-1}\right)$, the reactivity of the semiquinone with $\mathrm{O}_{2}$ is many orders of magnitude lower [109]. This problem seems to have been addressed in nature by the development of multicenter redox proteins with rapid internal electron transfers between the redox centers, permitting specific functions to be carried out by the individual centers. This concept arose from studies of milk xanthine oxidase, a particularly complex example containing, in addition to FAD, a molybdenum center and two discrete iron-sulfur centers of the spinach ferredoxin type (see $[110,111]$ for reviews). With this enzyme the multiphasic kinetics of reduction by substrate and reoxidation by $\mathrm{O}_{2}$ were explained on the assumption of xanthine donating two electron equivalents at the same time through the molybdenum centers, followed by the rate-limiting dissociation of urate and the immediate redistribution of reducing equivalents among the other redox centers, the distribution being governed solely by the relative redox potentials of the centers [112]. The validity of this concept was demonstrated by determination of the redox potentials, whose absolute values were in accord with the predictions from the rapidequilibrium concept $[113,114]$. With the $\mathrm{Mo}^{\mathrm{v}} / \mathrm{Mo}^{\mathrm{v}}$ couple having the lowest potential and one of the iron-sulfur centers the highest, it is thus possible to load the enzyme with a total of six electron equivalents from xanthine, although in the steady state of catalytic turnover it is doubtful that this stage would ever be reached. The reaction of $\mathrm{O}_{2}$ with the enzyme was shown to be with the flavin, since a deflavoenzyme could be prepared which was still reduced rapidly by xanthine, but reacted extremely slowly with $\mathrm{O}_{2}[115]$. The enzyme containing FAD in the fully reduced state was shown to react more rapidly with $\mathrm{O}_{2}$ than that containing $\mathrm{FADH}$, the former gave rise directly to $\mathrm{H}_{2} \mathrm{O}_{2}$ as product, while the latter, as expected, gave $\mathrm{O}_{2}^{-}[116-118]$. Thus the ' $\mathrm{O}_{2}^{-}$flux', the percentage of the total xanthine oxidation giving rise to $\mathrm{O}_{2}^{-}$, depends on the extent of electron loading of the enzyme by substrate in the steady state, the greater the degree of reduction the smaller the $\mathrm{O}_{2}^{-}$flux. In this enzyme the function of the iron-sulfur centers appears to be to act as electron sinks, allowing the Mo centers to achieve the $\mathrm{Mo}^{\mathrm{VI}}$ state for reaction with reducing substrate and the flavin to be in the $\mathrm{FADH}_{2}$ or FADH form for reaction with $\mathrm{O}_{2}$.

The concept of rapid internal equilibration of electrons within a multi-redox-center enzyme seems to apply fairly generally, with the different centers possessing discrete functions. For example, $P-450$ reductase contains both FAD and FMN, and the two flavins have quite different potentials [119]. The FAD has been shown to be the flavin reduced by NADPH in the catalytic reaction and FMN the flavin reacting with $P-450$. In catalysis the enzyme appears to function between the $3 \mathrm{e}^{-}$and the $1 \mathrm{e}^{-}$-reduced levels, with $\mathrm{FMNH}_{2}$ being the most reactive species with $P-450$, and rapid internal electron transfer between $\mathrm{FADH}^{-}$and $\mathrm{FMNH}^{\circ}$ at the $2 \mathrm{e}^{-}$level regenerating $\mathrm{FMNH}_{2}$ for reaction with a second molecule of $P-450$ [120].

Similar concepts apply in the actual interactions between discrete proteins in an intermolecular complex. This has been discussed in detail by Lambeth and Kamin [121] particularly with reference to the adrenal mitochondrial $P-450$ system (composed of a complex between the flavoprotein, NADPH adrenodoxin reductase, the $[2 \mathrm{Fe}-2 \mathrm{~S}]$ protein, adrenodoxin, and a steroid-specific $P-450$ ), E. coli sulfite reductase and spinach nitrite reductase. These all have the common theme of reducing equivalents from NADPH entering through the flavin component and finally leaving to the specific acceptor through a second or third redox center of the complex, with internal 'electron shuttling' being an important part of the overall electron transport process. 


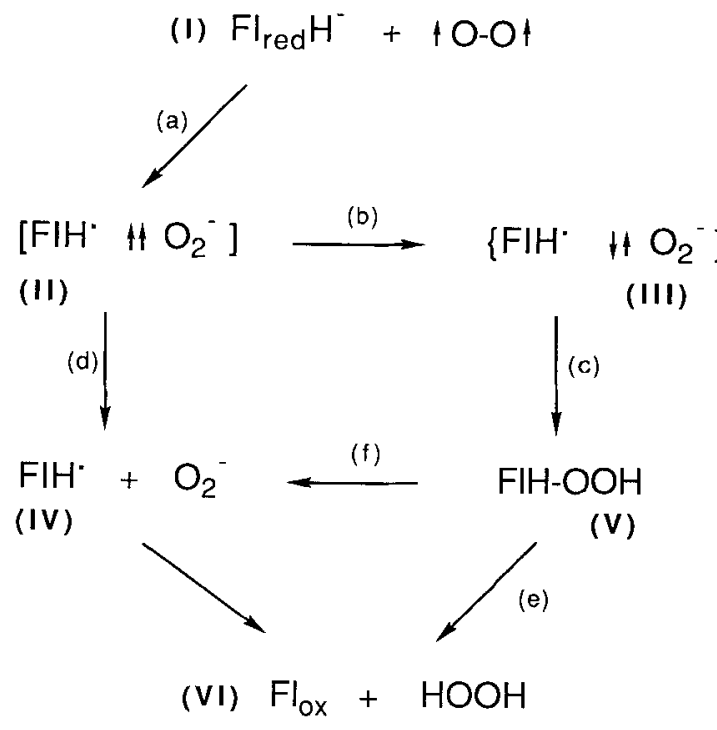

Scheme 9. Mode of activation of dioxygen by free flavin

\section{REACTIONS WITH OXYGEN}

\section{Reactions of free reduced flavin with oxygen}

Reduced flavin is one of the few biocatalysts which can efficiently reduce dioxygen. The mechanism by which this is brought about by free reduced flavin has recently been solved. The critical step in any chemical reaction of paramagnetic dioxygen is the inversion of the spin of one electron, a relatively slow process. Due to extensive delocalisation in a flavin radical, such an inversion is assumed to be comparatively facile. As shown in Scheme 9, which results from the work from the groups of Bruice [122, 123] and Anderson [124, 125], a first encounter results in the transfer of an electron from reduced flavin ( $\mathrm{I})$ to $\mathrm{O}_{2}$ to form a paramagnetic complex of $\mathrm{O}_{2}^{-}$and the flavin radical (II, step a). It should be pointed out that transfer of electrons from the flavin to $\mathrm{O}_{2}$ might occur at a distance of several nanometres and that in (II) the two species do not have to be in close contact.

Spin inversion of the unpaired flavin electron in complex (II), or physical rotation of one partner lead (step b) to the biradical complex (III), in which the two electrons have paired spins and can combine to give the covalent flavin $4 \mathrm{a}-$ hydroperoxide $(\mathrm{V}$, step $\mathrm{c})$. This will occur provided distance and orientation of flavin and superoxide is such as to allow formation of a thermodynamically stable bond. It is noteworthy that the point of bond formation corresponds to the locus of highest spin density in FlH [126]. The hydroperoxide (V) itself can dissociate heterolytically via step (e) to yield hydrogen peroxide and $\mathrm{Fl}_{\mathrm{ox}}(\mathrm{VI})$. As will be detailed below, dissociation of the complex (II) via (d) to yield free $\mathrm{FlH}^{\prime}$ (IV) and superoxide is a reaction competing with (b). The latter two species could also arise from homolytic cleavage of the hydroperoxide (V) via step (f), a conversion which, however, is chemically less likely.

Important experimental evidence supporting the sequences of Scheme 9 is obtained from experiments of Anderson [124]. An essentially quantitative formation of free neutral flavin radical can be observed in a pulse radiolysis experiment within $20 \mu$ s after the pulse. This species is converted to an intermediate in a very fast reaction, which is directly dependent on the concentration of $\mathrm{O}_{2}^{-}\left(k=7 \times 10^{8} \mathrm{M}^{-1} \mathrm{~s}^{-1}\right)$. The absorption spectrum of the intermediate is consistent with the presence of approximately $80 \%$ flavin hydroperoxide (V) and $20 \% \mathrm{Fl}_{\mathrm{ox}}$ (VI). At pH 6.5 the subsequent decay of (V) to (VI) is independent of $\mathrm{O}_{2}^{-}$concentration, $k=260 \mathrm{~s}^{-1}$. It follows that some $20 \%$ of (VI) must be formed from (II) bypassing (V). This probably involves direct $\mathrm{e}^{-}$transfer from (III) as will be discussed in the next section.

\section{Activation of oxygen by flavoproteins}

While many reduced flavoproteins react only slowly with molecular oxygen, there are also many which can react efficiently, some of them having the additional capacity of catalyzing the insertion of one atom of $\mathrm{O}$ from $\mathrm{O}_{2}$ into substrate. Accordingly they have been classified as either 'oxidases' or 'monooxygenases'. A characteristic of the 'monooxygenases' is the occurrence of the flavin 4a-hydroperoxide (V, Scheme 9) on the catalytic path. Its formation can be viewed as proceeding via steps (a), (b), and (c) (Scheme 9). This is consistent with recent pulse radiolysis experiments [128], in which immediately upon pulsing glucose oxidase at pH 6.0 and $p$-hydroxybenzoate hydroxylase at $\mathrm{pH} 6.5$ under conditions generating enzyme flavin radicals and $\mathrm{O}_{2}^{-}$, a species having the spectral characteristics of the neutral radical (cf. IV) were observed. This then converted to the hydroperoxide (V) in a second-order reaction with $\mathrm{O}_{2}^{-}$(rate $\approx 10^{9} \mathrm{M}^{-1} \mathrm{~s}^{-1}$ for glucose oxidase). The hydroperoxides subsequently decayed to the oxidized enzyme (VI) at a rate of $350 \mathrm{~s}^{-1}$ for glucose oxidase, and $70-80 \mathrm{~s}^{-1}$ for $p$-hydroxybenzoate hydroxylase. In sharp contrast to this, pulsing at $\mathrm{pH} 8.5$ lead to exclusive formation of the enzyme-bound flavin radical anions, $\mathrm{Fl}^{-}$, no hydroperoxide (V) being formed subsequently.

The initial product of reaction of aqueous electrons from the radiation pulse is the enzyme anionic flavin radical $\mathrm{Fl}^{-}$ followed by rapid protonation to give the neutral FlH (IV). The $\mathrm{p} K_{\mathrm{a}}$ of the glucose oxidase radical is 7.3 [129] and that of $p$-hydroxybenzoate hydroxylase $\approx 7.1$ (R. F. Anderson and V. Massey, unpublished results). At low $\mathrm{pH}$, neutral $\mathrm{FlH}^{\circ}$ will bind $\mathrm{O}_{2}^{-}$in an orientation compatible with radical pairing, thus yielding (III). In contrast to this, at high $\mathrm{pH}$, repulsion of the two negatively charged species $\mathrm{Fl}^{-}$and $\mathrm{O}_{2}^{-}$appears efficiently to prevent any encounter.

These rather straightforward interpretations have to be compared with the oxygen reaction of reduced glucose oxidase and of reduced hydroxylases (e.g. p-hydroxybenzoate hydroxylase) in the absence of substrate or effectors, the socalled 'oxidase' reaction. With these two enzymes a rapid second-order reaction with $\mathrm{O}_{2}$ ensues which leads to formation of oxidized enzyme and $\mathrm{H}_{2} \mathrm{O}_{2}$, no radical species, superoxide or covalent hydroperoxides such as (V) being found [128]. Most importantly, rates appreciably faster than the decay of enzyme-bound flavin 4a-hydroperoxide to $\mathrm{Fl}_{\mathrm{ox}}$ (cf. conversion of V to VI via step e, Scheme 9) can be observed, precluding a pathway over steps (c) and (e), i.e. over (V). On the other hand, a spin inversion must occur at some stage during the formation of these products. Thus, the sequences of Scheme 9 are clearly not sufficient to explain the oxidase reaction and the question arises as to whether a second, parallel, mechanism has to be formulated. The 'direct' reaction of reduced flavin with $\mathrm{O}_{2}$ to yield a covalent adduct over a 'low lying flavin triplet state' has been proposed [131]. For the discussion of this seeming contradiction the reaction of free reduced flavin can be taken as the standard case, in which no particular effects due to protein interactions will stabilize or destabilize any intermediates. Rapid-reaction 


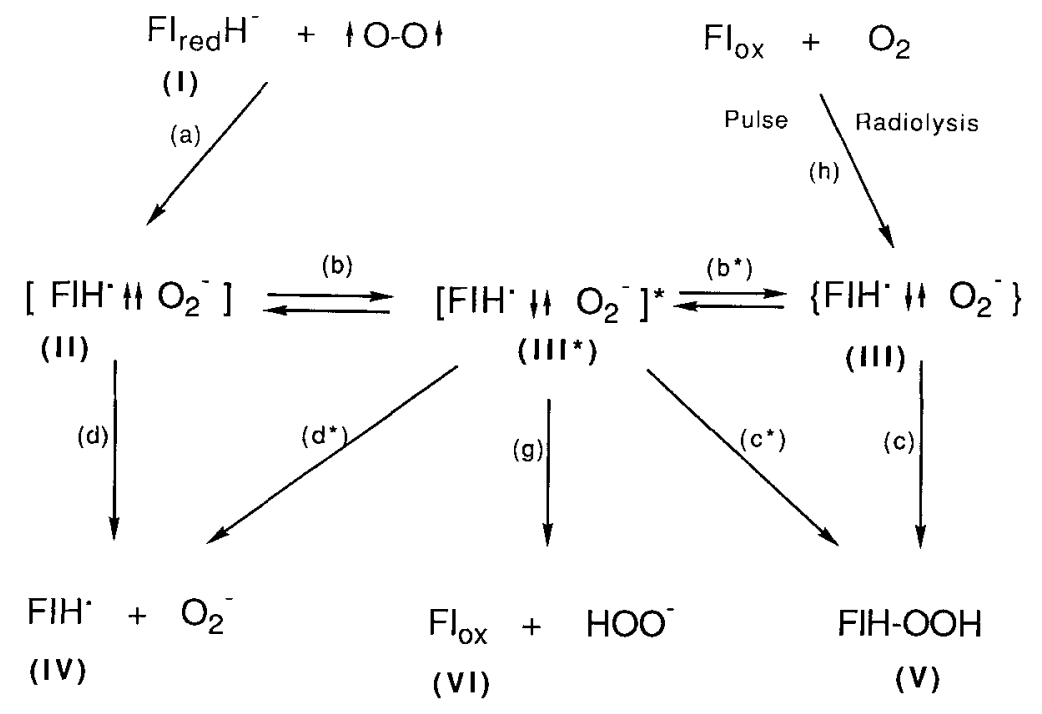

Scheme 10. Possible routes for the reduction of oxygen by reduced enzymes such as glucose oxidase or $\mathrm{p}$-hydroxybenzoate hydroxylase (in the ahsence of substrate), and mode of reaction of intermediates by pulse radiolysis. See text for details

studies on the reaction of free $\mathrm{Fl}_{\text {red }} \mathrm{H}^{-}$with $\mathrm{O}_{2}$ require the formation of an intermediate to account for the observed kinetics [132, 133]. With reduced flavoprotein a hydroperoxide may be stabilized depending on the starting conditions (e.g. presence of substrate or effectors with $p$-hydroxybenzoate hydroxylase). Thus the simplest interpretation would be: when a covalent hydroperoxide is on the reaction pathway it is likely to be observable; if none can be observed, most probably it is not formed, or, at best, it is a transition state.

There is evidence supporting this interpretation. Reduced flavodoxin reacts in a second-order reaction with $\mathrm{O}_{2}$ to give the neutral radical $\mathrm{FlH}^{-}$and $\mathrm{O}_{2}^{-}$. The $\mathrm{FlH}$. formed does not react further efficiently. From the X-ray structure of flavodoxin it is apparent that the space around the flavin positions which are candidates for formation of a covalent bond with $\mathrm{O}_{2}^{-}$is insufficient to accommodate the hydroperoxide product, and that access of $\mathrm{O}_{2}$ is severely limited [8]. Only part of the benzene moiety of the flavin and the $8-\mathrm{CH}_{3}$ function are exposed to solvent. Thus, in this case the reaction will be likely to proceed via steps (a) and (d) of Scheme 9, formation of (III) being possible, but abortive in the sense that the collapse of the radical pair cannot yield (V).

The two different sets of dioxygen reactivities exemplified by $p$-hydroxybenzoate hydroxylase, and the reaction of reduced glucose oxidase with $\mathrm{O}_{2}$ can thus be rationalized according to the steps of Scheme 10, an extension of Scheme 9. The right-hand side represents the (artificial) reaction, in which $\mathrm{FlH}$ and $\mathrm{O}_{2}^{-}$are formed by pulse radiolysis and then combine to yield a 'productive' complex (III, step h), which collapses to the covalent hydroperoxide (V, step c). This requires that from the beginning of the reaction the active center is set up in order to stabilize (V), i.e. to prevent release of $\mathrm{HOO}^{-}$.

On the left-hand side the 'oxidase' reaction is shown in which the paramagnetic complex (II) is formed (step a) similarly as in Scheme 9. For formation of the final products $\mathrm{Fl}_{\mathrm{ox}}+\mathrm{HOO}^{-}$spin inversion is envisaged as occurring during conversion of (II) to (III*). The crucial point in this scheme would be the difference between the two diamagnetic species (III) and (III*). In our opinion this might lie simply in the different properties of (III) and (III*). Thus (III) would appear to be able to collapse to a thermodynamically metastable hydroperoxide such as (V); (III*), in contrast, would not and thus reacts further by transfer of $1 \mathrm{e}^{-}+\mathrm{H}^{+}$to $\mathrm{O}_{2}^{-}$(step g), or dissociates (steps d).

These differences might result from steric restrictions as, for example, in the case of flavodoxin. There the inability to form (V) might force dissociation of either complex (II) or $\left(\mathrm{III}^{*}\right)$ to yield $\mathrm{FlH}^{*}+\mathrm{O}_{2}^{-}$. In the case of $p$-hydroxybenzoate hydroxylase, it has been shown [134] that the presence of substrate or product results in substantial changes of the geometry of the flavin, implying modification of the protein structure around it. It is thus easily conceivable that such effects contribute to the stabilization of the hydroperoxide (V), also since this consists largely in preventing the dissociation of $\mathrm{HOO}^{-}$, i.e. abstraction of the $\mathrm{N}(5)$ hydrogen as $\mathrm{H}^{+}$. Binding of substrate introduces an additional net negative charge at the active center and this might be at the origin of the different reactivities. In this context the course of the reaction might be affected by the different state of charge of the species from which it originates.

\section{ACTIVATION OF FLAVIN-HYDROPEROXIDE OXYGEN}

Following the primary step of oxygen activation leading to formation of a flavin hydroperoxide as discussed above, the hydroperoxide moiety requires activation and/or modulation of its chemical activity for reaction with a second substrate. The key molecule is, of course, the flavin 4ahydroperoxide (cf. also V, Schemes 9 and 10) itself, a molecule of unusual properties:<smiles>[R]N1C2=NC(=O)NC(=O)C2(OO)Nc2cc(C)c(C)cc21</smiles> 


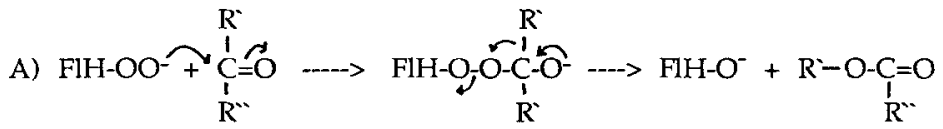

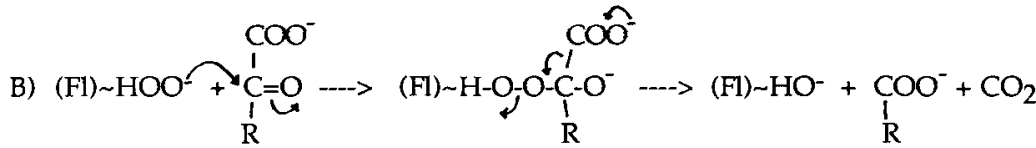

Scheme 11. (A) Baeyer-Villiger mechanism formulated by Walsh et al. [138] for the oxidative ring expansion of cyclohexanone monooxygenase. (B) Mechanism for the oxidative decarboxylation of L-lactate oxidase involving enzyme-bound $\mathrm{H}_{2} \mathrm{O}_{2}$ and oxo acid product

As found mainly by Bruice and colleagues (see $[2,134-$ 136] for reviews) its chemical reactivity resembles more that of peracids than that of alkylperoxides, and indeed it might be viewed as a derivative of barbituric acid. The first striking property is the unusually low $\mathrm{p} K_{\mathrm{a}}$ of $7-8$ estimated by Favaudon for the distal oxygen [137], which correlates with the similarly low value of $9.1-9.5$ for the 4a-hydroxyl function of the related flavin 4a-hydroxide [134]. This has been attributed to the inductive effects of the substituents around position $4 \mathrm{a}$. Basically the three following mechanisms can be formulated for the reactions of this hydroperoxide: (a) nucleophilic activation, (b) radical activation, (c) electrophilic activation.

The nucleophilic activation does not pose mechanistic difficulties. As has been formulated for cyclohexanone monooxygenase [138], it implies nucleophilic attack of the distal oxygen of the hydroperoxide to a carbonyl residue of the substrate and a subsequent Baeyer-Villiger rearrangement as shown on Scheme 11 (A). With enzymes such as L-lactate oxidase essentially the same scheme could be applied, with the difference that hydroperoxide formed at the active center reacts with the enzyme-bound $\alpha$-oxoacid before dissociation of the products occurs and induces oxidative decarboxylation by the similar mechanism shown in Scheme 11 (B).

However, as discussed in a previous section, no evidence for intermediate formation of a flavin 4a-hydroperoxide could be obtained with L-lactate oxidase, $\mathrm{Fl}_{\mathrm{ox}}$ and $\mathrm{H}_{2} \mathrm{O}_{2}$ being the products formed directly from $\mathrm{E} \sim \mathrm{Fl}_{\text {red }} \mathrm{H}^{-}$and oxygen. From the mechanistic point of view, the oxygen reactivity of L-lactate oxidase is that of an 'oxidase', although from its overall function it might better be called a 'monooxygenase'.

A special case is most probably represented by the bioluminescent reaction of bacterial luciferase. Also with this FMNdependent enzyme a metastable flavin 4a-hydroperoxide is formed upon reaction of reduced luciferase-bound $\mathrm{FMNH}^{-}$ with oxygen in a primary step (b) of Scheme 12 [139]. The unique behavior of this enzyme should be noted in this context since here FMN behaves as a true coenzyme, and not as a tightly bound prosthetic group as in the majority of flavin enzymes. Free $\mathrm{Fl}_{\text {red }} \mathrm{H}^{-}$is first bound by luciferase (step a), on which it carries out catalysis, then being released as FMN upon completion of the catalytic cycle.

The actual bioluminescent reaction starts upon addition of a long-chain aldehyde $\mathrm{R}-\mathrm{CH}=\mathrm{O}$ (chain length $=8-14$ for the in vitro reaction, 14 for the natural substrate in vivo) and leads to formation of the flavin 4a-hydroxide, carboxylic acid (R-COOH), and light (Scheme 12, reaction c). Subsequently water is split off (step d), FMN dissociates (step e), and can be rereduced by an FMN reductase (see [140] for a review).

Of particular interest here are the processes which lead to the production of light, i.e. the chemical events producing the
a) $\mathrm{L}+\mathrm{FMN}_{\mathrm{red}} \mathrm{H}^{-}$

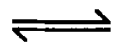
$\mathrm{L} \sim \mathrm{FMN}_{\text {red }} \mathrm{H}^{-}$
b) $\mathrm{L} \sim \mathrm{FMN}_{\mathrm{red}} \mathrm{H}^{-}+\mathrm{O}_{2}+\mathrm{H}^{+}$

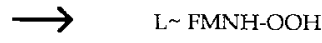
c) $\mathrm{L} \sim \mathrm{FMNH}-\mathrm{OOH}+\mathrm{R}-\mathrm{CH}=\mathrm{O}$

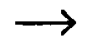
$\mathrm{L} \sim \mathrm{FMNH}-\mathrm{OH}+\mathrm{R}-\mathrm{COOH}+h v$
d) L FMNH-OH

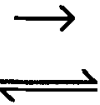
$\mathrm{L} \sim \mathrm{FMN}+\mathrm{H}_{2} \mathrm{O}$
e) L FMN
$\mathrm{L}+\mathrm{FMN}$

Scheme 12. Sequence of reactions occurring during the catalytic cycle of bacterial luciferase $(L)$

energy which is needed to populate the excited state of the emitter. These events take place during step (c) of Scheme 12 and have not yet been clarified satisfactorily. An early proposal [141], by which a Baeyer-Villiger mechanism is operative as discussed above for the reaction of cyclohexanone monooxygenase, is probably not correct as suggested by recent results [143]. Present indications point towards a so-called CIEEL mechanism (chemically induced electron exchange luminescence), for which an adaptation of a general scheme [142] for the bacterial luciferase reaction has been formulated $[143,144]$. Upon binding of luciferase the formation of a peroxyhemiacetal by nucleophilic attack of the hydroperoxide moiety on the aldehyde carbonyl is envisaged to occur [141]. The key step involves an intermediate intramolecular transfer of an electron from the flavin N(5) region to the peroxide, which 'weakens' the peroxide bond, inducing fragmentation. Subsequently the electron is transferred back to an unoccupied orbital of the 4a,5-dihydroflavin radical cation yielding an excited state of the flavin 4a-hydroxide. Relaxation of the latter by emission of light $\left(\lambda_{\max } \approx 490 \mathrm{~nm}\right)$ concludes the events of step (c) of Scheme 12 [144]. It should be pointed out that fluorescent proteins can take part in the reaction and lead to emission of light with either blue-shifted [145] or redshifted spectra [146]. Mechanistically the involvement of these proteins requires some adjustments of the basic mechanism of Scheme 12, for the discussion of which we refer to the original literature $[144,145]$.

In conclusion, the mechanism of bacterial luciferase can be viewed as being initiated by a nucleophilic reaction of the peroxide, most probably followed by a radical-type oxidation of the aldehyde, and concomitant generation of an excited state, thus by a combination of nucleophilic activation and electron transfer.

As to electrophilic activation, there are two typical subclasses of flavin enzymes which are reasonably assumed to function by this mechanism. The first is that exemplified by the microsomal 'mixed-function monooxygenase', an enzyme involved in detoxification processes in the liver [147], which 

a) $\mathrm{E} \sim \mathrm{Fl}_{\mathrm{red}} \mathrm{H}^{-}+\mathrm{O}_{2}+\mathrm{H}^{+} \longrightarrow \mathrm{E} \sim \mathrm{FlH}-\mathrm{OOH}$
b) $\mathrm{E} \sim \mathrm{FlH}-\mathrm{OOH}+\mathrm{S} \quad \longrightarrow \quad \mathrm{E} \sim \mathrm{X} \sim \mathrm{Y}$
c) $E \sim X \sim Y$
$\longrightarrow \quad \mathrm{E} \sim \mathrm{FlH}-\mathrm{OH} \sim \mathrm{SOH}$
d) $\mathrm{E} \sim \mathrm{FIH}-\mathrm{OH} \sim \mathrm{SOH}$
$\longrightarrow \quad \mathrm{E} \sim \mathrm{Fl}_{\mathrm{Ox}}+\mathrm{H}_{2} \mathrm{O}+\mathrm{S}-\mathrm{OH}$

Scheme 13. Sequence of reactions catalyzed by $\mathrm{p}$-hydroxybenzoate hydroxylase. $\mathrm{X}$ and $\mathrm{Y}$ denote chromophores occurring as intermediates during the insertion of oxygen into phenolates, proposed to be derived from the flavin and/or the substrate. The chemical structure of the intermediates has not yet been elucidated

metabolizes a variety of nucleophilic substrates $(\mathrm{Nu})$ having the typical functions $\mathrm{R}_{3} \mathrm{~N}$ or $\mathrm{R}-\mathrm{SH}(\mathrm{R}=$ alkyl or $\mathrm{H})$, but also others such as $I^{-}[148]$. This mechanism is best depicted by a nucleophilic displacement at the distal atom of the hydroperoxide [127]:

$$
\mathrm{FlH}-\mathrm{O}-\mathrm{O}-\mathrm{H}+\mathrm{Nu} \rightarrow \mathrm{FlH}_{-}-\mathrm{O}^{-}+\mathrm{HO}-\mathrm{Nu}^{+} .
$$

This rather straightforward mechanism contrasts with that of the so-called 'hydroxylases' which, in spite of having been the first to receive extensive attention $[149,150]$, still resist elucidation in their key step (c) of Scheme 13. The cycle is initiated, as in the previous cases, by formation of the hydroperoxide (V) (step a).

In the presence of substrate, which must be activated by the presence of a phenolic function, the hydroperoxide complex is converted (step b) to a species which stands out by its characteristic absorption spectrum, having a maximum in the region $350-420 \mathrm{~nm}$ with high molar absorption [150-152]. Subsequently this species is transformed to the complex of enzyme-bound flavin 4a-hydroxide and product (step c), which can dissociate into the components as shown by step $d$. The fact that only (nucleophilic) phenolates will react suggests that the reaction is initiated by nucleophilic attack of the latter onto the electrophilic hydroperoxide to form an intermediate complex denoted as $X \sim Y$ in Scheme 13 (where $X$ stands for some product resulting from reaction of the flavin hydroperoxide and $\mathrm{Y}$ for some form originating from the substrate which interacts with $\mathrm{X}$ ). This intermediate has become known as 'intermediate II' in the pertinent literature [150]. The structure of this intermediate is still elusive, but is logically expected to enclose the key for the elucidation of the detailed mechanism. This has fostered several structural and mechanistic proposals, none of which, however, has withstood experimental verification.

An interesting proposal has been put forward recently based on the absorption of the radicals obtained upon $1 \mathrm{e}^{-}$ oxidation of typical substrates of $p$-hydroxybenzoate hydroxylase which, superimposed on that of the flavin 4a-hydroperoxide, yields a calculated spectrum very similar to that of the intermediate $E \sim X \sim Y$ [153]. If true, this assumption would predict that $\mathrm{E} \sim \mathrm{X} \sim \mathrm{Y}$ should have an EPR signal or exhibit magnetic susceptibility. Up to now, however, experiments aimed at testing this have been negative. In view of this it is not reasonable to discuss further such detailed mechanisms in the context of the present review; further ideas and experimental evidence clearly are needed for elucidation of the full catalytic mechanisms of the aromatic hydroxylases.

\section{REFERENCES}

1. Walsh, C. T. (1980) Acc. Chem. Res. 13, $148-155$.

2. Bruice, T. C. (1980) Acc. Chem. Res. 13, 256-262.

3. Massey, V. \& Ghisla, S. (1983) in Biological oxidations (Sund, H. \& Ullrich, V., eds) pp. 114-139, Springer, Berlin.

4. Müller, F. (1983) Top. Curr. Chem. 108, 71-107.

5. Barman, B. G. \& Tollin, G. (1972) Biochemistry 11, 4755-4759.

6. Gomez-Moreno, C., Choy, M. \& Edmondson, D. E. (1979) $J$. Biol. Chem. 254, 7630-7635.

7. Ghisla, S. \& Massey, V. (1986) Biochem. J. 239, 1-12.

8. Burnett, R. M., Darling, G. D., Kendall, D. W., LeQuesne, M., Mayhew, S. G., Smith, W. W. \& Ludwig, M. L. (1974) J. Biol. Chem. 249, 4383-4392.

9. Schulz, G. E., Schirmer, R. H. \& Pai, E. F. (1982) J. Mol. Biol. $160,287-308$.

10. Weijer, W. J., Hofsteenge, J., Beintema, J. J., Wierenga, R. K. \& Drenth, J. (1983) Eur. J. Biochem. 133, 109-118.

11. Mathews, F. S. \& Zia, Z. x. (1987) in Flavins and flavoproteins (Edmondson, D. E. \& McCormick, D. B., eds) pp. 123-132, W. deGruyter, Berlin.

12. Williamson, G. \& Edmondson, D. E. (1985) Biochemistry 24, $7790-7797$.

13. Ghisla, S., Kenney, W. C., Knappe, W. R., McIntire, W. \& Singer, T. P. (1980) Biochemistry 19, 2537-2544.

14. Ghisla, S. \& Mayhew, S. G. (1980) Methods Enzymol. 66, $241-$ 253.

15. Schöllnhammer, G. \& Hemmerich, P. (1974) Eur. J. Biochem. $44,561-577$

16. Mayhew, S. G., Whitfield, C. D., Ghisla, S. \& Schuman-Jorns, M. (1970) Eur. J. Biochem. 44, 579-591.

17. Vervoort, J., Müller, F., Lee, J., van den Berg, W. A. M. \& Moonen, C. T. W. (1986) Biochemistry 25, 8062-8067.

18. Ghisla, S. \& Massey, V. (1980) J. Biol. Chem. 255, 5688-5696.

19. Brüstlein, M. \& Bruice, T. C. (1972) J. Am. Chem. Soc. 94, $6548-6549$.

20. Pai, E. G. \& Schulz, G. E. (1983) J. Biol. Chem. 258, $1752-$ 1757.

21. Walsh, C. T., Schonbrunn, A. \& Abeles, R. H. (1971) J. Biol. Chem. 246, 6855-6866.

22. Porter, D. J. T., Voet, J. B. \& Bright, H. J. (1973) J. Biol. Chem. $248,4400-4416$

23. Mathews, F. S. \& Xia, Z. x. (1987) Flavins and flavoproteins (Edmondson, D. E. \& McCormick, D. B., eds) pp. 123-132, W. deGruyter, Berlin, New York.

24. Lederer, F. \& Mathews, F. S. (1987) Flavins and flavoproteins (Edmondson, D. E. \& McCormick, D. B., eds) pp. 133-142, W. deGruyter, Berlin, New York.

25. Lindquist, Y. \& Bränden, C. I. (1985) Proc. Natl Acad. Sci. USA $82,6855-6859$.

26. Manstein, D. J., Massey, V., Ghisla, S. \& Pai, E. F. (1988) Biochemistry 27, 2300-2305.

27. Schonbrunn, A., Abeles, R. H., Walsh, C. T., Ghisla, S., Ogata, H. \& Massey, V. (1976) Biochemistry 15, 1798-1807.

28. Ghisla, S., Olson, S. T., Massey, V. \& Lhoste, J.-M. (1979) Biochemistry 18, 4733-4742.

29. Pompon, F. \& Lederer, F. (1985) Eur. J. Biochem. 148, $145-$ 154.

30. Ghisla, S. \& Massey, V. (1977) J. Biol. Chem. 252, 6729-6735.

31. Lock ridge, O., Massey, V. \& Sullivan, P. A. (1972) J. Biol. Chem. $247,8097-8106$.

32. Lederer, F. (1974) Eur. J. Biochem. 46, 393- 399.

33. Williams, C. H. Jr, Arscott, L. D. \& Swenson, R. P. (1984) in Flavins and flavoproteins (Bray, R. C., Engel, P. C. \& Mayhew, S. G., eds) pp. 95-109, W. deGruyter, Berlin, New York.

34. D'Silva, C., Williams, C. H. Jr \& Massey, V. (1987) Biochemistry 26, $1717-1722$.

35. Cornforth, J. W. (1959) J. Lipid Res. 1, 3-28.

36. Ghisla, S. (1984) in Flavins and flavoproteins (Bray, R. C., Engel, P. C. \& Mayhew, S. G., eds) pp. 385-401, W. deGruyter, Berlin, New York.

37. Fendrich, G. \& Abeles, R. H. (1982) Biochemistry 21, 66856695. 
38. Schopfer, L. M., Massey, V., Ghisla, S. \& Thorpe, C. (1988) Biochemistry 27, 6599-6611.

39. Manstein, D. J., Pai, E. F., Schopfer, L. M. \& Massey, V. (1986) Biochemistry 25, 6807-6816.

40. Reinsch, J., Katz, A., Wean, J., Aprahamian, G. \& McFarland, J. R. (1980) J. Biol. Chem. 255, 9093-9097.

41. Pohl, B., Raichle, Th. \& Ghisla, S. (1986) Eur. J. Biochem. 160, $109-115$.

42. Ghisla, S., Thorpe, C. \& Massey, V. (1984) Biochemistry 23, $3154-3161$.

43. Ikeda, Y., Hine, D. G., Okamura, I. K. \& Tanaka, K. (1985) J. Biol. Chem. 260, 1326-1337.

44. Jencks, W. P. (1981) Chem. Soc. Rev. 10, 345-375.

45. Beinert, H. \& Page, E. (1956) J. Biol. Chem. 225, 479-497.

46. Thorpe, C. \& Massey, V. (1983) Biochemistry 22, $2972-2978$.

47. Thorpe, C. (1987) in Flavins and flavoproteins (Edmondson, D. E. \& McCormick, D. B., eds) pp. 149-157, W. deGruyter, Berlin, New York.

48. Lau, S. M., Powell, P., Büttner, H., Ghisla, S. \& Thorpe, C. (1986) Biochemistry 25, 4187-4189.

49. Silverman, R. B. (1984) Biochemistry 23, 5206-5213.

50. Walker, M. C. \& Edmondson, D. E. (1987) in Flavins and flavoproteins (Edmondson, D. E. \& McCormick, D. B., eds) pp. $699-703$, W. deGruyter, Berlin, New York.

51. Mincey, T., Tayrien, G., Mildvan, A. S. \& Abeles, R. H. (1980) Proc. Natl Acad. Sci. USA 77, $7099-7101$.

52. Geissler, J., Ghisla, S. \& Kroneck, P. M. H. (1986) Eur. J. Biochem. 160, 93-100.

53. Fisher, H. F., Ofner, P., Conn, E. E., Vennesland, B. \& Westheimer, F. H. (1953) J. Biol. Chem. 202, 687-697.

54. Yamazaki, S., Tsai, L., Stadtman, T. C., Jacobsen, F. S. \& Walsh, C. (1980) J. Biol. Chem. 255, 9025-9027

55. You, K., Arnold, L. J., Allison, W. S. \& Kaplan, N. O. (1978) Trends Biochem. Sci. 3, 265-268.

56. Williams, C. H. Jr (1976) The enzymes, vol. 13 (Boyer, P. D., ed.) pp. 89-173, Academic Press, New York.

57. Massey, V. \& Veeger, C. (1961) Biochim. Biophys. Acta 48, $33-$ 47.

58. Searls, R. L., Peters, J. B. \& Sanadi, D. R. (1961) J. Biol. Chem. 236, 2317-2322.

59. Massey, V. \& Williams, C. H. Jr (1965) J. Biol. Chem. 240, $4470-4480$

60. Kosower, E. B. (1966) in Flavins and flavoproteins (Slater, E. C., ed.) pp. 1-14, Elsevier, Amsterdam.

61. Massey, V. \& Ghisla, S. (1974) Ann. NY Acad. Sci. 227, 446-465

62. Matthews, R. G. \& Williams, C. H. Jr (1976) J. Biol. Chem. 251, $3956-3964$

63. Williams, C. H. Jr, Arscott, L. D. \& Schulz, G. E. (1982) Proc. Natl Acad. Sci. USA 79, 2199-2201.

64. Rice, D. W., Schulz, G. E. \& Guest, J. R. (1984) J. Mol. Biol. I74, 483-496.

65. Krohne-Erich, G., Schirmer, R. H. \& Untucht-Grau, R. (1977) Eur. J. Biochem. 80, 65-71.

66. Brown, N. L., Ford, S. T., Pridmore, R. D. \& Fritzinger, D. (1983) Biochemistry 22, 4089-4095.

67. Thieme, R., Pai, E. F., Schirmer, R. H. \& Schulz, G. E. (1981) J. Mol. Biol. 152, 763-782.

68. Karplus, P. A. \& Schulz, G. E. (1987) in Flavins and flavoproteins (Edmondson, D. E. \& McCormick, D. B., eds) pp. 45-54, W. deGruyter, Berlin, New York.

69. Massey, V., Ghisla, S., Ermler, V. \& Schulz (1987) in Flavins and flavoproteins (Edmondson, D. E. \& McCormick, D. B., eds) pp. $79-84$, W. deGruyter, Berlin, New York.

70. Massey, V., Miller, S. M., Ballou, D, P., Williams, C. H. Jr, Moore, M., Distefano, M. D. \& Walsh, C. T. (1987) in Flavins and flavoproteins (Edmondson, D. E. \& McCormick, D. B., eds) pp. $41-44$, W. deGruyter, Berlin, New York.

71. Schierbeek, A. J., Drenth, J. \& Hol, W. G. J. (1984) in Flavins and flavoproteins (Bray, R. C., Engel, P. C. \& Mayhew, S. G., eds) p. 147, W. deGruyter, Berlin, New York.

72. Reference deleted.
73. Stephens, P. E., Lewis, H. M., Darlison, M. G. \& Guest, J. R (1983) Eur. J. Biochem. 135, 519-527.

74. Westphal, A. H. \& deKok, A. (1988) Eur. J. Biochem. 172, $299-$ 305.

75. Greer, S. \& Perham, R. N. (1986) Biochemistry 25, 2736- 2742.

76. Massey, V., Matthews, R. G., Foust, G. P., Howell, L. G., Williams, C. H. Jr, Zanetti, G. \& Ronchi, S. (1970) in Pyridine nucleotide-dependent dehydrogenases (Sund, H., ed.) pp. $393-$ 411, Springer, Heidelberg.

77. Bulger, J. E. \& Brandt, K. G. (1971) J. Biol. Chem. 246, 5570-$5577 \& 5578-5587$.

78. Huber, P. W. \& Brandt, K. B. (1980) Biochemistry 19, 4568-4575.

79. Mannervik, B., Boggaram, V., Carlberg, I. \& Larson, K. (1979) in Flavins and flavoproteins (Yagi, K. \& Yamano, T., eds) pp. 173-187, University Park Press, Baltimore.

80. Arscott, L. D., Thorpe, C. \& Williams, C. H. Jr (1981) Biochemistry $20,1513-1520$.

81. Thorpe, C. \& Williams, C. H. Jr (1976) J. Biol. Chem. 251, $3553-3557$.

82. Thorpe, C. \& Williams, C. H. Jr (1981) Biochemistry 20, 1507 1513.

83. Matthews, R. G., Ballou, D. P. \& Williams, C. H. Jr (1977) J. Biol. Chem. 252, 3199-3207.

84. Matthews, R. G., Ballou, D. P. \& Williams, C. H. Jr (1979) J. Biol. Chem. 254, 4974-4981.

85. Fairlamb, A. H. \& Cerami, A. (1985) Mol. Biochem. Parasitol. 14, $187-196$.

86. Shames, S. L., Fairlamb, A. H., Cerami, A. \& Walsh, C. T. (1986) Biochemistry 25, $3519-3526$.

87. Krauth-Siegel, L., Enders, B., Henderson, G. B., Fairlamb, A. H. \& Schirmer, R. H. (1987) Eur. J. Biochem. 164, 123-128.

88. Fox, B. S. \& Walsh, C. T. (1982) J. Biol. Chem. 257, $2498-$ 2503.

89. Fox, B. S. \& Walsh, C. T. (1983) Biochemistry 22, 4082-4088.

90. Schultz, P. G., Au, K. G. \& Walsh, C. T. (1985) Biochemistry $24,6840-6848$

91. Walsh, C. T., Moore, M. J. \& Distefano, M. D. (1987) in Flavins and flavoproteins (Edmondson, D. E. \& McCormick, D. B., eds) pp. $13-28$, W. deGruyter, Berlin, New York.

92. Moore, M. J. \& Walsh, C. T. (1989) Biochemistry, in the press.

93. Distefano, M. D., Au, K. G. \& Walsh, C. T. (1989) Biochemistry, in the press.

94. Sahlman, L., Lambeir, A. M., Lindskog, S. \& Dunford, H. B. (1984) J. Biol. Chem. 259, 12403-12408.

95. Sandström, A.\& Lindskog, S. (1987) in Flavins and flavoproteins (Edmondson, D. E. \& McCormick, D. B., eds) pp. 33-36, W. deGruyter, Berlin, New York.

96. Miller, S., Ballou, D. P., Massey, V., Williams, C. H. Jr \& Walsh, C. T. (1986) J. Biol. Chem. 261, 8081-8084.

97. Miller, S., Moore, J. J., Massey, V., Williams, C. H. Jr, Distefano, M. D., Ballou, D. P. \& Walsh, C. T. (1989) Biochemistry, in the press.

98. Sandström, A. \& Lindskog, S. (1987) Eur. J. Biochem. 164, $243-$ 249.

99. Moore, M. J., Distefano, M. D., Walsh, C. T., Miller, S., Massey, V., Williams, C. H. Jr \& Ballou, D. P. (1987) in Flavins and flavoproteins (Edmondson, D. E. \& McCormick, D. B., eds) pp. 37-40, W. deGruyter, Berlin, New York.

100. Stankovich, M. T. \& Bard, A. J. (1977) J. Electroanal. Chem. $75,487-505$.

101. Casa, J. S. \& Jones, M. M. (1980) J. Inorg. Nucl. Chem. 42, 99 102.

102. Sahlman, L., Lambier, A. M. \& Lindskog, S. (1986) Eur. $J$. Biochem. 156, $479-488$.

103. Casola, L. \& Massey, V. (1966) J. Biol. Chem. 241, 4985-4993.

104. Strittmatter, P. (1965) J. Biol. Chem. 240, $4481-4487$.

105. Gorelick, R. J., Schopfer, L. M., Ballou, D. P., Massey, V. \& Thorpe, C. (1985) Biochemistry 24,6830-6839.

106. Simondson, R. P., Weger, P. C., Salemme, F. R. \& Tollin, G. (1982) Biochemistry 24, 6366-6375. 
107. Tollin, G., Cheddar, G., Watkins, J. A., Meyer, T. E. \& Cusanovich, M. A. (1984) Biochemistry 23, 6345-6349.

108. Weber, P. C. \& Tollin, G. (1985) J. Biol. Chem. 260, $5568-5573$.

109. Mayhew, S. G. \& Ludwig, M. L. (1975) The enzymes (Boyer, P. D., ed.) pp. 57-118, Academic Press, New York.

110. Bray, R. C. (1975) The enzymes (Boyer, P. D., ed.) pp. 300419, Academic Press, New York.

111. Hille, R. \& Massey, V. (1985) in Molybdenum enzymes (Spiro, T. P., ed.) pp. 443-518, Academic Press, New York.

112. Olson, J. S., Ballou, D. P., Palmer, G. \& Massey, V. (1974) J. Biol. Chem. 249, 4363-4382.

113. Barber, M. J., Bray, R. C., Cammack, R. \& Coughlan, M. P. (1977) Biochem. J. 163, 279-289.

114. Porras, A. G. \& Palmer, G. (1982) J. Biol. Chem. 257, 11617 11626

115. Komai, H., Massey, V. \& Palmer, G. (1969) J. Biol. Chem. 244, $1692-1700$

116. Olson, J. S., Ballou, D. P., Palmer, G. \& Massey, V. (1974) J. Biol. Chem. 249, $4350-4362$

117. Hille, R. \& Massey, V. (1981) J. Biol. Chem. 256, 9090-9095.

118. Porras, A. G., Olson, J. S. \& Palmer, G. (1981) J. Biol. Chem. $256,9096-9103$

119. Iyanagi, T., Makino, N. \& Mason, H. S. (1974) Biochemistry $13,1701-1710$

120. Vermilion, J. L., Ballou, D. P., Massey, V. \& Coon, M. J. (1981) J. Biol. Chem. 256, 266-277.

121. Kamin, H. \& Lambeth, J. C. (1982) in Flavins and flavoproteins (Massey, V. \& Williams, C. H. Jr, eds) pp. 665-666, Elsevier, New York.

122. Kemal, C., Chan, T. W. \& Bruice, T. C. (1977) J. Am. Chem. Soc. 99, $7272-7286$.

123. Eberlein, G. \& Bruice, T. C. (1982) J. Am. Chem. Soc. 104 $1449-1452$

124. Anderson, R. F. (1982) in Flavins and flavoproteins (Massey, V. \& Williams, C. H. Jr, eds) pp. $278-283$, Elsevier, New York.

125. Anderson, R. F. (1984) in Flavins and flavoproteins (Bray, R. C., Engel, P. C. \& Mayhew, S. G., eds) pp. 57-60, W. deGruyter, Berlin, New York

126. Müller, F., Ghisla, S. \& Bacher, A. (1988) in Vitamine II (Isler, O., Brubacher, G., Ghisla, S. \& Kräutler, B., eds) pp. 94-95, Thieme Verlag, Stuttgart, New York.

127. Ballou, D. P. (1984) in Flavins and flavoproteins (Bray, R. C., Engel, P. C. \& Mayhew, S. G., eds) pp. 605-618, W. deGruyter, Berlin, New York.

128. Massey, V., Schopfer, L. M. \& Anderson, R. F. (1988) in Oxidases and related enzyme systems (King, T. E., Mason, H. S. \& Morrison, M. M., eds) pp. 147-166, Alan Liss, New York.

129. Stankovich, M. T., Schopfer, L. M. \& Massey, V. (1978) J. Biol. Chem. 253, $4971-4979$.
130. Reference deleted.

131. Hemmerich, P. \& Wessiak, A. (1976) in Flavins and flavoproteins (Singer, T. P., ed.) pp. 9-22, Elsevier, Amsterdam, New York.

132. Gibson, Q. H. \& Hastings, J. W. (1962) Biochem. I. 83, $368-$ 377.

133. Massey, V., Palmer, G. \& Ballou, D. P. (1973) in Oxidases and related systems (King, T. E., Mason, H. S. \& Morrison, M. eds) pp. 25-43, University Park Press, Baltimore.

134. Bruice, T. C. (1982) in Flavins and flavoproteins (Massey, V. \& Williams. C. H. Jr, eds) pp. 265-277, Elsevier, New York.

135. Bruice, T. C. (1984) Israel J. Chem. 24, 54-61.

136. Bruice, T. C. (1984) in Flavins and flavoproteins (Bray, R. C,, Engel, P. C. \& Mayhew, S. G., eds) pp. 45-55, W. deGruyter, Berlin, New York.

137. Favaudon, V. (1977) Eur. J. Biochem. 78, $293-307$.

138. Ryerson, C. C., Ballou, D. P. \& Walsh, C. T. (1982) Biochemistry $21,2644-2655$.

139. Hastings, J. W., Balny, C., LePeuch, C. \& Douzou, P. (1973) Proc. Natl Acad. Sci. USA 70, 3468 - 3472.

140. Hastings, J. W. \& Nealson, K. H. (1977) Annu. Rev. Microbiol. $31,549-595$.

141. Eberhard, A. \& Hastings, J. W. (1972) Biochem. Biophys. Res. Commun. 47, $348-353$

142. Schuster, G. B. (1979) Acc. Chem. Res. 12, 366-373.

143. Macheroux, P., Eckstein, J. \& Ghisla, S. (1987) in Flavins and flavoproteins (Edmondson, D. E. \& McCormick, D. B., eds) pp. $613-619$, W. deGruyter, Berlin, New York.

144. Ghisla, S., Eckstein, J. \& Macheroux, P. (1987) in Flavins and flavoproteins (Edmondson, D. E. \& McCormick, D. B., eds) pp. $601-612$, W. deGruyter, Berlin, New York.

145. Lee, J., O'Kane, D. J. \& Visser, J. W. G. (1985) Biochemistry $24,1476-1483$

146. Macheroux, P., Schmidt, K. U., Steinerstauch, P., Buntic, G., Hastings, J. W. \& Ghisla, S. (1987) Biochem. Biophys. Res. Commun. 146, 101-106.

147. Poulsen, L. L. \& Ziegler, D. M. (1979) J. Biol. Chem. 254, 6449 6455

148. Jones, K. \& Ballou, D. P. (1984) in Flavins and flavoproteins (Bray, R. C., Engel, P. C. \& Mayhew, S. G., eds) pp. 619622 , W. deGruyter, Berlin, New York.

149. Spector, T. \& Massey, V. (1972) J. Biol. Chem. 247, 5632- 5636

150. Entsch, B., Ballou, D. P. \& Massey, V. (1976) J. Biol. Chem. $251,1550-1563$

151. Wessiak, A., Schopfer, L. M. \& Massey, V. (1984) J. Biol. Chem. $259,12547-12556$

152. Detmer, K. \& Massey, V. (1985) J. Biol. Chem. 160, 5998-6005.

153. Anderson, R. F., Patel, K. B. \& Stratford, M. R. L. (1987) $J$. Biol. Chem. 262, 17475-17479. 